Review Article

\title{
Late Quaternary to Holocene Southwest Monsoon Reconstruction: A Review Based on Lake and Wetland Systems (Studies Carried Out During 2011-2016)
}

\author{
H ACHYUTHAN ${ }^{1}, *$, A FAROOQUI ${ }^{2}$, V GOPAL ${ }^{1}$, B PHARTIYAL ${ }^{2}$ and A LONE ${ }^{1}$ \\ ${ }^{1}$ Department of Geology, Anna University, Chennai 600 025, India \\ ${ }^{2}$ Birbal Sahni Institute of Paleosciences, Lucknow 226 007, India
}

(Received on 10 April 2016; Accepted on 25 May 2016)

\begin{abstract}
The recent trends in Late Quaternary researches, particularly, for the Holocene period is mainly focused on reconstructing the past climate dynamics, fluctuations in the intensity of the southwest monsoon (SWM) and applications of these datasets for predicting future trends. During the years 2010-2015, the published data, although shows chronological constraints, by covering different physiographies of India, which presently display a highly variable climate from hot to cold desert and from high to low rainfall region. An integrated multidisciplinary, multiproxy data provide a comprehensive understanding of the trend in climate change, from moist mid-Holocene to dry Late Holocene conditions from the Indian subcontinent although with a slight variation in time brackets which is attributed to external forces responding to varied landscape, geographical setting and altitudinal changes. Most of the lake records show a decline in SWM since the middle Holocene with intermittent intense wetter conditions. This allowed the lake margins to shrink and expand. Some lakes hold the signatures of abrupt and extreme events such as the $8200 \mathrm{yr}$ BP solar insolation event, 4200 extreme aridity, 3800 dry and warm conditions, Medieval warm period (MWP) and the Little Ice age (LIA) events. Till date, however, these data are few and far in between and the need of the day is to rigorously generate quantification of SWM intensity using lake sediments and compile the dataset for climatic modeling such as the Regional Climate Models (REGCMS) to predict future climate change if any with greater degree of correctness.
\end{abstract}

Keywords: Lake Sediments, Southwest Monsoon, Extreme Events, Vegetation, Dry and Warm Periods

\section{Introduction}

The nation's economy is largely dependent on food and agricultural production and food security. Monsoon dependent countries such as ours, the monsoonal rains are looked forward to with great anticipation and hence it is important to understand and evaluate meteorological data for future predictions with high accuracy. Climate models such as general climate model (GCM) and regional climate models (REGCM) for long term prediction are carried out using various parameters as its data input and the amount of rainfall (past and present) records are vital parameters. Varied past environmental conditions have left geochemical signals in the sediment records that can be used to interpret paleo-ecological and paleoenvironmental histories (Meyers and Teranes, 2001). Physical and chemical characteristics of lakes and ocean sediments, peat bogs, loess, and speleothems have been used as important proxies for reconstructing long-term climate variability of the Holocene period and beyond. However, the reconstruction of the past monsoonal record is not accurate as there are discrepancies in analytical precision and resolution.

Instrumental and historical information and records about climate conditions of the past are restricted to the last few centuries and millennia, respectively. For this purpose lake sediments are often used as one of the important proxies for the reconstruction of paleoenvironments because they can demonstrate continuity in environmental and seasonal

*Authorfor Correspondence: E-mail: hachyuthan0@gmail.com 
sensitivity, therefore providing high resolution paleoenvironmental and climatic information (Zhang et al., 2004; Hodell et al., 1999; Harrison et al., 1993; Street-Perrott and Harrison, 1985). As the formation and deposition of lacustrine sediments are dominantly controlled by climate processes and catchment geology, the analysed sediment properties, referred as 'palaeoclimate proxy data' are used as indicators of the variability of past environmental conditions as well as of the impact of human influences on lake systems and their catchment areas. Numerous lake catchments and their hydrologic settings in industrialized countries have witnessed strong anthropogenic impacts during the last ca 150 years (Zolitschka et al., 2015). The deposition of sediment incorporates environmental information as proxies relating to sedimentary structure and composition. Each sedimentary column represents a paleoenvironmental archive that requires a measure of depositional age (i.e. a chronostratigraphy) to yield a meaningful time-series of their proxies. Whilst both natural climate change and human-influenced environmental changes are likely to be recorded in Holocene sediments (Shen et al., 2005), it is critical to evaluate the influence of human activities on the reliability of sedimentary proxies in inferring the past climate change (Yang et al., 1997; Zhang et al., 2010). Lakes are major sinks not only for sediment deposition in a closed system, but also are major sinks for carbon, carbon sequestration and also hold signatures for reconstructing paleoenvironments.

Elemental and isotopic analyses of sediments provide useful information regarding provenance and climate change, either as an independent method (Robinson, 1994; Piovano et al., 2004; Ng and King, 2004; Yanes et al., 2006; Ruiz-Fernandez et al., 2007; Tanaka et al., 2007; Xue et al., 2007; Minyuk et al., 2007) or associated with pollen and isotopic data (Osborne et al., 1993; Goslar et al., 1999; Brauer et al., 2000; Mingram et al., 2004; Dressler et al., 2006; Parker et al., 2006; Schettler et al., 2007). The determination of mineralogical composition of lake sediments is another useful tool for paleoenvironmental reconstruction of the area around the lake catchment and wetland ecosystems (Luque and Julia, 2002; Sakai et al., 2005; Fagel and Boes, 2008; Fagel and Mackay, 2008). These researches show an integration of various disciplines with multiproxy study and interdisciplinary approach, which has become necessary for a spatio-temporal comparisons. In the last five years use of proxies like-sedimentology, mineral magnetism, phytoliths, palynology, diatoms, thecamoebians, geochemistry, radioisotopes and application of various dating techniques has been extensively used to address issues related to paleoclimate, paleovegetation, paleoprecipitation, possible climate-culture relationship, abrupt climatic events etc. The archives used are mainly lacustrine and wetland sediments, although a few fluvial, aeolian and coastal wetland records are available.

The Holocene period began approximately $\sim 11500$ yrs ago and this period is marked by the evolution and decline of human cultures and establishing agriculture practices (Possehl, 1994). Relatively warm and cooler conditions during this period are also characterised by marine transgression and regression which has resulted in shifting of the coastlines world over impacting human settlements/ migrations. Such oscillations resulted in geomorphological changes, sedimentation patterns in coastal plains and inland areas, forming back waters, estuaries, formation of marine-terraces, spits, sand barriers, beach ridges and shifting of river courses (Wolf et al., 2008).

Precession of the earth's orbit around the sun has been attributed to cause significant changes in the seasonal distribution of surface heating during the Holocene period (Maher and Hu, 2006). For the North African and Southwest Asian monsoons, a wealth of proxy data reveals major northward expansion of monsoonal rain in the early and mid-Holocene period (Maher and $\mathrm{Hu}, 2006$ ). Lake level data from the North African region show that the lacustrine deposition was initiated at around $14500 \mathrm{yr}$ BP, which is the onset of the 'African Humid Period' (Street and Grove, 1979; Street-Perrott and Harrison, 1984; Gasse, 2000). A high-resolution, well-dated deep sea sediment record of aeolian flux studied from the ODP site $658 \mathrm{C}$, Mauritania) corroborates well with the onset of humid conditions and dates which is reflected by a steep rise in biogenic carbonate, opal and a decrease in terrigeneous flux. The high terrigeneous flux at the ODP site $658 \mathrm{C}$ indicate increased monsoonal intensity and precipitation from the end of the younger Dryas to around $5500 \mathrm{yr}$ BP that is when the African Humid period came to an abrupt end (deMenocal et al., 2000). Lake level data, also collate 
well for the mid-Holocene (around $6000 \mathrm{yr}$ BP) indicating conditions were still wetter than present day across North Africa, East Africa, The Arabian Peninsula (Jolly et al., 1998; Maher and Hu, 2006). Across this monsoonal belt, the major fluctuation from wetter to arid conditions has been dated to between 5000 and $6000 \mathrm{yr} \mathrm{BP}$ and is also associated with the ongoing decline in the boreal summer insolation (deMenocal et al., 2000; Maher and Hu, 2006).

Parallel patterns in the SWM intensity have been recorded in the Qunf cave/Oman/Arabian sea and Tibetan regions. For example Fleitman's et al. (2003) $\delta^{18} \mathrm{O}$ data of the speleothem samples from Qunf Cave, Oman, indicates peak precipitation from around 10000 to $\sim 5000 \mathrm{yr}$ BP with a stepped decline from $\sim 8000 \mathrm{yr}$ BP. For Tibet, Gasse et al. (1996) and van Campo et al. (1996) provide multiproxy records (pollen, radiocarbon, stable isotopes) from two sets of Holocene lake sequences (lakes Sumxi and Bangong). They identified major strengthening of the summer monsoon around $11500 \mathrm{yr} \mathrm{BP}$ with rainfall maxima from 10800 to $9600 \mathrm{yr} \mathrm{BP}$ and 8200 to $7200 \mathrm{yr} \mathrm{BP}$, separated by an arid interval centered around 8800 $\mathrm{yr}$ BP. The trend towards long term aridity is observed after $6800 \mathrm{yr}$ BP. These authors further conclude that the paleoenvironmental fluctuations in western Tibet are in phase with those of North Africa.

In comparison, during the Holocene period, most part of the southern Indian peninsula was vulnerable even to the slightest rise in sea level in response to the natural short term extreme events. An increased understanding of the temperature record in the few past years through a multi-proxy studies have strengthened our confidence in assessing the middle Holocene warming trend associated with the rise in sea level to reduced precipitation/regression in shoreline which is primarily the result of human activities since the last 3000 to $2000 \mathrm{yr}$ BP. A considerable high resolution regional paleoclimate data are now available for a comprehensive integration with archaeological data in order to manage the vulnerable areas that may be a subject of immediate concern for the welfare of mankind, for economic and societal benefits in the future (Brock and Wikler, 2006). A compilation of paleoclimate data generated from the high altitudinal and tropical lakes of Indian and sites elsewhere are presented in Tables 1 and 2 .
In this paper, we present a review of work that describes the recent trends in paleoclimate studies carried out in different parts of India based on lacustrine and paleolake deposits. These climate records are concerned with changes in regional and local climate, monsoonal shifts, past environmental and tectonic changes. For convenience, we have discussed the work and findings under six headings: a) palaeoclimatic records from the Himalayan zone, b) the Ganga Plain, c) the Central India, d) the Western region, e). the southern India and f) the coastal and wetland region (Fig. 1).

\section{Late Quaternary-Historical Climatic Records from the Himalayan Zone: The Present Scenario}

Several high resolution and well-dated records of Late Quaternary climatic variations are documented from the Himalayan region both from the northeast and northwest. Lake deposits from all these regions have provided continuous and high-resolution record of the past conditions (Das et al., 2010). The most commonly used proxies are pollen, stables isotopes $\left(\delta^{13} \mathrm{C}, \delta^{18} \mathrm{O}\right)$, ostracods, grain size, mineral magnetism and various geochemical variables.

The high altitude moraine dammed lake Paru Co provided an 11,000 yr BP perspective record of local and synoptic-scale of the SWM variability and fluctuations in the lake levels. The sedimentological data indicate that the SWM was considerably weaker between 10,900 and 10,700 yr BP, but rapidly ameliorated to maximum intensity by $10,100 \mathrm{yr}$ BP (Bird et al., 2014).

Kar et al. (2015) reported modern pollen assemblages from Hamtah and Chhatru glaciers, Lahaul-Spiti. Wünnemann et al. (2010) studied the Tso Kar lake (Ladakh), to reconstruct the possible monsoonal impact on the hydrology of the lake basin during the last 15,000 yr BP using geochemical, mineral composition, aquatic pollen and non-pollen palynomorphs. The maximum glacier advance was observed between the LGM and ca 15,000 yr BP while considerable summer monsoon moisture supply occurred in the periods around 12,500 $\mathrm{yr} \mathrm{BP}$ and between ca 11,500 and 8,600 yr BP. The maximum lake level rise occurred around 11,800 yr BP with a maximum extent between 8,500 and 7,000 yr BP under warm-moist climate conditions. Weakening in summer monsoon after 8,000 yr BP caused shrinkage of the 
Table 1: Paleoclimate records of the lake sediments from India and world high altitude lakes

\begin{tabular}{|c|c|c|c|c|c|}
\hline S.No. & $\begin{array}{l}\text { Country and lake name } \\
\text { depth }\end{array}$ & Altitude/ & Protocols used & Inferences & References \\
\hline 1. & Tso Moriri Lake (Ladakh) & $4600 \mathrm{~m}$ & Stable isotope & $\begin{array}{l}\text { This region experienced increasing Indian Summer Monsoon (ISM) } \\
\text { precipitation between ca. } 13.1 \text { and } 11.7 \mathrm{cal} \mathrm{ka} \text { and highest ISM } \\
\text { precipitation during the early Holocene }(11.2-8.5 \mathrm{cal} \mathrm{ka})\end{array}$ & Mishra et al., 2015 \\
\hline 2. & Lake Towuti (Indonesia) & $293 \mathrm{~m}$ & Magnetic measurements & $\begin{array}{l}\text { Magnetic parameters are controlled not only by detrital influx, which } \\
\text { usually correlates with climate, but also by in situ geochemical } \\
\text { processes, which do not always correlate directly with climate }\end{array}$ & Tamuntuan et al., 2015 \\
\hline 3. & $\begin{array}{l}\text { Nainital and Sattal lakes } \\
\text { (India) }\end{array}$ & $\begin{array}{l}1938 \mathrm{~m} \text { and } \\
1,370 \mathrm{~m}\end{array}$ & $\begin{array}{l}\text { Major oxides and } \\
\text { phosphorus fractionation }\end{array}$ & $\begin{array}{l}\text { High concentration of } \mathrm{P} \text { and } \mathrm{S} \text { in Nainital lake shows that it is affected } \\
\text { both by natural and anthropogenic activities. The biogenic silica is high } \\
\text { in Sattal when compared with other lakes }\end{array}$ & Purushothaman et al., 2015 \\
\hline 4. & Lake Tota (Colombian Andes) & $3015 \mathrm{~m}$ & $\mathrm{AMS}^{14} \mathrm{C}$ radiocarbon & $\begin{array}{l}\text { A period of high lake level is observed at Tota Lake from } 4000 \text { to } \\
3620 \text { cal. yrs BP }\end{array}$ & Cardozo et al., 2014 \\
\hline 5. & Wular Lake (India) & $1580 \mathrm{~m}$ & $\begin{array}{l}\text { Textural and geochemical } \\
\text { studies }\end{array}$ & $\begin{array}{l}\text { Sediments indicate low (recent) to moderate (past) chemical weathering } \\
\text { of the source rocks, which are consistent with the prevailing climate in } \\
\text { the area. It is a well-established fact that in cold climatic regions, } \\
\text { chemical weathering is less when compared to physical weathering, } \\
\text { thus this study presents a classical example of climate control on } \\
\text { weathering }\end{array}$ & Rashid et al., 2013 \\
\hline 6. & Lake Blanc Huez (French) & $2543 \mathrm{~m}$ & $\begin{array}{l}\text { AMS }{ }^{14} \mathrm{C},{ }^{210} \mathrm{~Pb} \text { dating } \\
\text { and TOC }\end{array}$ & $\begin{array}{l}\text { According to the available core chronologies, higher glacial activity may } \\
\text { have occurred during the } 3600-3300 \text { cal. BP colder event and during } \\
\text { the more recent Little Ice Age }\end{array}$ & Garçon et al., 2012 \\
\hline 7. & Northern Andes & $2540 \mathrm{~m}$ & $\begin{array}{l}\text { XRF Geochemical analysis } \\
\text { (Lake Fúquene) }\end{array}$ & & Bogotá et al., 2011 \\
\hline 8. & Lake Pumoyum* & $\sim 5030 \mathrm{~m}$ & ${ }^{14} \mathrm{C}$ dating & $\begin{array}{l}\text { Changes in organic matter sources in the sediment cores from the } \\
\text { last glacial to the Holocene (after_19 cal ka BP) were estimated by } \\
14 \mathrm{C} \text { measurements of TOC and plant residues in three sediment cores }\end{array}$ & Watanabe et al., 2010 \\
\hline 9. & Lake Respomuso (Spain) & $2130 \mathrm{~m}$ & $\mathrm{XRF}$ and $\mathrm{XRD}$ & $\begin{array}{l}\text { The distribution of trace elements ( } \mathrm{As}, \mathrm{Cd}, \mathrm{Ni}, \mathrm{Cu}, \mathrm{Cr}, \mathrm{Co}, \mathrm{Mn}, \mathrm{Pb} \\
\text { and } \mathrm{Zn} \text { ) and their relationships with the major elements and mineral } \\
\text { components evaluated by PCA showed that the metals are of } \\
\text { geogenic origin }\end{array}$ & Zaharescu et al., 2009 \\
\hline 10. & Lake Titicaca (tropical Andes) & $3810 \mathrm{~m}$ & Diatom biostratigraphy & $\begin{array}{l}\text { During the mid-Holocene ( } 6000-3500 \text { cal yr BP), the abundance } \\
\text { of the saline taxon Chaetoceros muelleri, coupled with high } \\
\text { abundances of epiphytic and epipelic diatoms, indicates maximum } \\
\text { salinity and lowest lake levels in the entire } 30000 \text { year record }\end{array}$ & Tapia et al., 2003 \\
\hline
\end{tabular}


Table 2: Paleoclimate records of India and Tropical lakes of the world

\begin{tabular}{|c|c|c|c|c|c|}
\hline S.No. & Country and lake name & Depth & Protocols used & Inferences & References \\
\hline 1. & Lake Kivu (East Africa) & $1463 \mathrm{~m}$ & $\begin{array}{l}\text { XRF and High-resolution } \\
\text { seismic }\end{array}$ & $\begin{array}{l}\text { The onset of carbonate preservation since the } 1970 \text { s that is currently } \\
\text { observed in the sediment could indicate that hydrothermal discharge } \\
\text { has recently increased in the lake }\end{array}$ & Ross et al., 2015 \\
\hline 2. & Pookot Lake (India) & $775 \mathrm{~m}$ & $\begin{array}{l}\text { Magnetic susceptibility } \\
\& \text { AMS }\end{array}$ & The vegetation history and climate for the past $\sim 3100$ years. & Veena et al., 2014 \\
\hline 3. & $\begin{array}{l}\text { Lake McKenzie } \\
\text { (SE Queensland) }\end{array}$ & $85 \mathrm{~m}$ & $\begin{array}{l}\text { Microfossils and } \\
\text { geochemistry }\end{array}$ & $\begin{array}{l}\text { A slowing or ceasing of sediment accumulation occurred during the } \\
\text { time period from ca. } 18.3 \text { to } 14.0 \mathrm{cal} \text { kyr BP }\end{array}$ & Atahan et al., 2014 \\
\hline 4. & Vembanad lake (India) & - & $\begin{array}{l}\text { Physical and geochemical } \\
\text { parameters }\end{array}$ & $\begin{array}{l}\text { Vembanad Lake have indicated the chances of chemical transformation } \\
\text { of mercury and the potential hazard if thedeposited mercury fractions } \\
\text { are remobilized }\end{array}$ & Mohan et al., 2014 \\
\hline 5. & Yanchi lake (NW China) & $1195 \mathrm{~m}$ & $\begin{array}{l}\text { Grain-size, mineral } \\
\text { composition and geoche- } \\
\text { mical proxies }\end{array}$ & $\begin{array}{l}\text { The depositional environment is stable and the lake level is relatively } \\
\text { high during the Late Glacial and the early Holocene }\end{array}$ & Yu et al., 2013 \\
\hline 6. & Bera lake (Malaysia) & $25-30 \mathrm{~m}$ & $\begin{array}{l}\text { Radioisotopes and } \\
\text { sediment quality indices }\end{array}$ & $\begin{array}{l}\text { Aquatic life threatens by the some toxic metals especially by As, Fe, } \\
\text { and } \mathrm{Cr} \text { metals }\end{array}$ & Gharibreza et al., 2012 \\
\hline 7. & Lake Valencia, Venezuela & $400 \mathrm{~m}$ & AMS \& Geochemical & $\begin{array}{l}\text { From the latest Pleistocene to the earliest Holocene, total organic } \\
\text { carbon (TOC) substantially increased from } 2.2 \text { to } 10 \% \text {, while total } \\
\text { organic carbon over total nitrogen (TOC/ TN) decreased from as high } \\
\text { as } 34 \text { to as low as } 10\end{array}$ & Xu and Jaffe (2008) \\
\hline .8 & Lake Naivasha, Kenya & - & $\begin{array}{l}\text { Numerical and statistical } \\
\text { analyses }\end{array}$ & $\begin{array}{l}\text { Within-lake variability of surface sediment chironomid assemblages in } \\
\text { the fairly large }(\sim 100-170 \mathrm{~km} 2 \text { since } 1983) \text { and shallow } \\
\text { (Zmax }=5-8 \mathrm{~m} \text { ) fluctuating tropical lake }\end{array}$ & Eggermont et al., 2007 \\
\hline 9. & Lago Verde (Mexico) & $149 \mathrm{~m}$ & Limnology & The highest anthropogenic impact was reached by ca. 1988 & Caballero et al., 2006 \\
\hline 10. & Lake Abiyata (Ethiopia) & $1577 \mathrm{~m}$ & Diatoms and pollen & $\begin{array}{l}\text { The drastic drought of the end of the } 19 \text { th century (around } 1890 \mathrm{AD} \text {; } \\
68-66 \mathrm{~cm} \text { ), or the deforestation and reforestation of the escarpments } \\
\text { in the early } 1970 \mathrm{~s}\end{array}$ & Legesse et al., 2002 \\
\hline
\end{tabular}




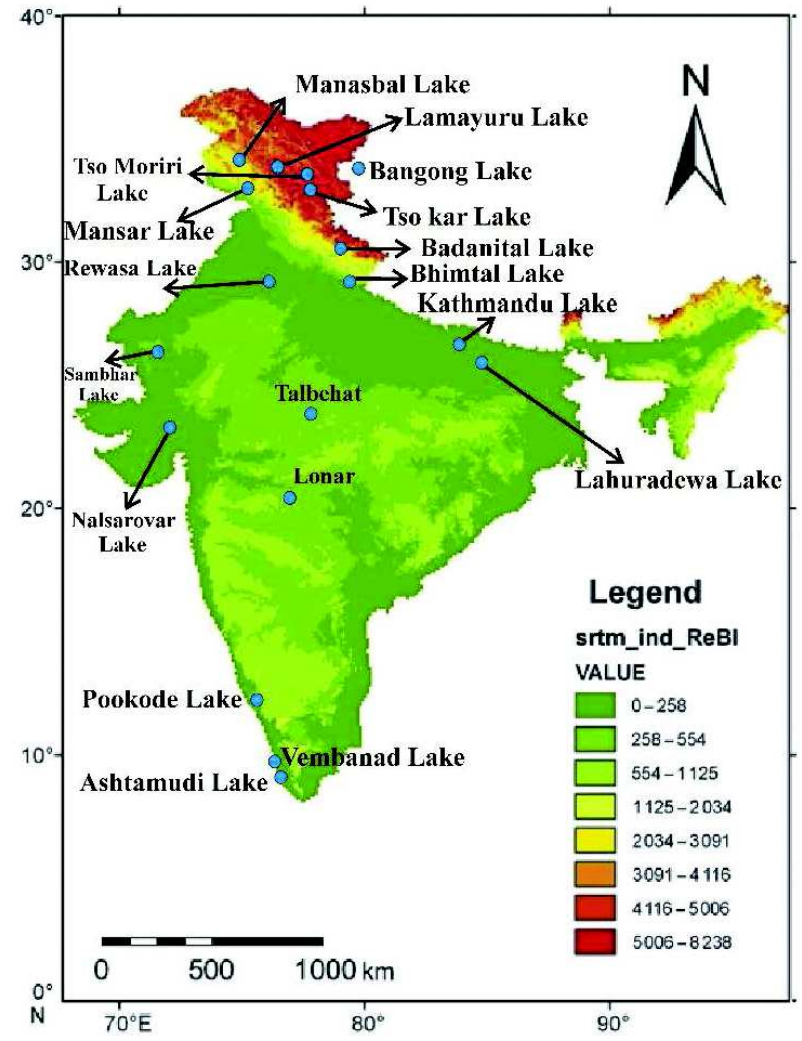

Fig. 1: Map showing some important lakes sediment cores that were used for paleoclimate reconstruction studies (Modified from Keerthi 2014)

lake to its lowest stand at about 4,200 yr BP, with the return of permafrost activity (Fig. 2). Three major lakes occurred due to deglaciation after the Last Glacial maximum (LGM) and Holocene warming (Phartiyal et al., 2013; Nag and Phartiyal, 2014) along the $136 \mathrm{~km}$ stretch of the present day Indus River valley that existed around 17,000-13,000 yr BP (Rizong paleolake) occupying $35 \mathrm{~km}$ of the valley length, 14-5 yr BP (Khalsi-Saspol paleolake) $55 \mathrm{~km}$ and between 12,000-1,000 yr BP (Spituk-Leh paleolake) $40 \mathrm{~km}$ length. Phartiyal et al. (2015) recorded the changing depositional regimes since the last 48,000 yr BP from the Tangtse Valley with varied sedimentary architecture, fluvial episodes, lacustrine pulses, flood events, colluvial and Aeolian sediments. The site was located near the vicinity of the Karakorum Fault. They also pointed out sixth lake basin of Pangong Tso towards the west, occupying the present day Tangtse Valley, that existed between 9,000-5,000 yr BP coinciding with periods of high lake levels in Tibet and China. The data generated indicated monsoon

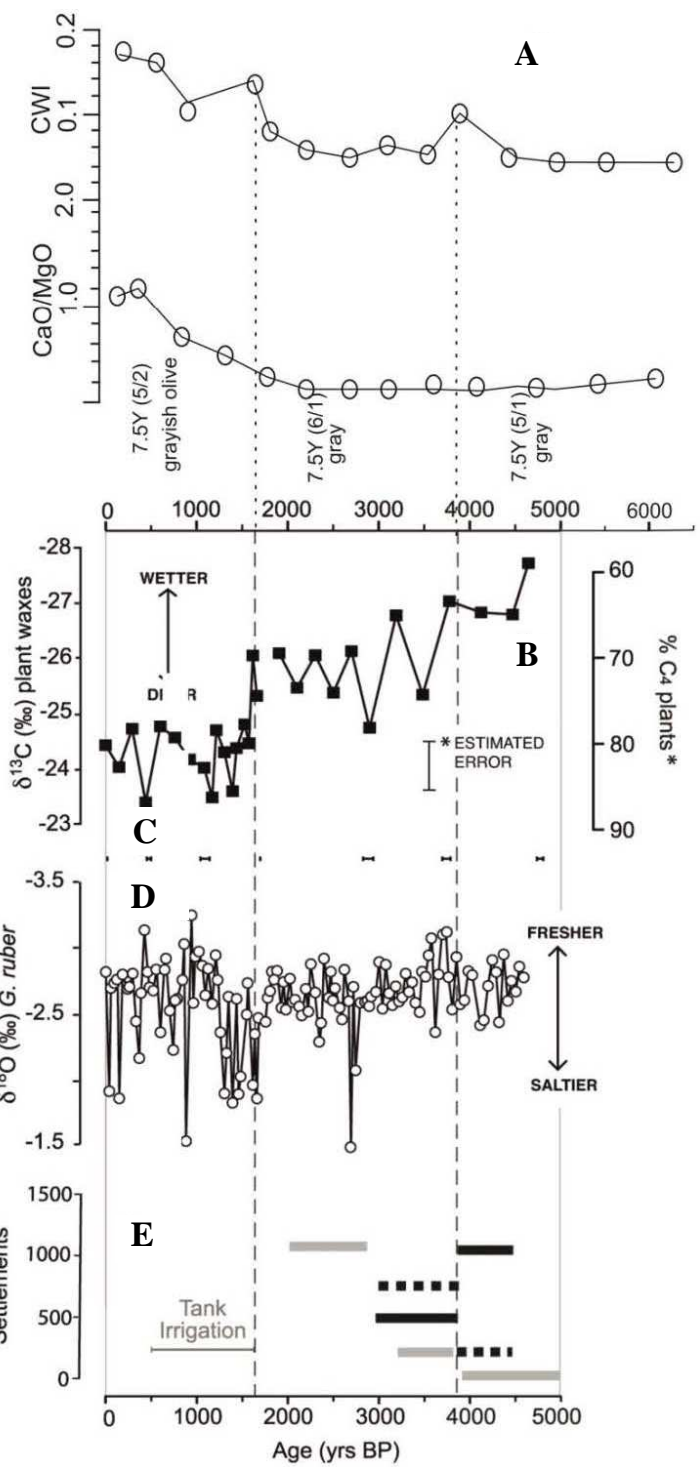

Fig. 2: (A) Represents the $\mathrm{CWI}$ and $\mathrm{CaO} / \mathrm{MgO}$ graph of the Pookode lake in correlation with the graphs plotted following Ponton et al. (2012). The CWI values show good relation of warm and arid climate around 3800 and 1700 yrs BP. This also indicates drought in the southern region during the late Holocene $1700 \mathrm{yr}$ $B P$, which also coincides well with the tank construction, (B) represent the $\delta^{13} \mathrm{C}$ values of the leaf wax record from $16 \mathrm{~A}$ sediment core off the Godavari river mouth, $(C)$ calibrated radiocarbon ages of the sediment core $16 \mathrm{~A}$, (D) $\delta^{18} \mathrm{O}$ measured on Globigerinoides ruber from 16 A sediment core, (E) Number of settlements based on archaeological data expressed as totals over culturally defined time intervals (see auxiliary material). In solid gray, sites from the Deccan Plateau (Andhra Pradesh, Karnataka, Maharashtra). In solid black, Indus (Harappan) sites from the dry Baluchistan, Sindh, Gujarat, Cholistan and lower Punjab. In dashed black, sites from rainier upper Punjab and Haryana following Ponton (2012) 
intensification over the Indian subcontinent around $48,000 \mathrm{yr}$ BP followed by drier and arid conditions around 30,000-21,000 yr BP.

Mishra et al. (2014) studied the hydrochemical, geochemical, mineralogical and sedimentology of the Tso Moriri Lake (Ladakh) sediments, isotopic composition $\left(\delta^{18} \mathrm{O}\right.$ and $\left.\delta \mathrm{D}\right)$ of the inflowing stream water and the data indicated that Tso Moriri Lake is an evaporative lake with contributions from both westerly source (snow melt) and Indian summer monsoon precipitation. The lacustrine sediment variables from Lake Bhimtal, (Uttrakhand) studied by Choudhary et al. (2013) presented the 100-year record of paleo-productivity and changes in organic matter in lake revealing a sharp increase in lake productivity over the last two decades. However, anthropogenic influences in the catchment area point to a recent increase in the trophic circumstances of the lake.

The tectonically and structurally controlled Badanital Lake dated from $\sim 5,100 \mathrm{yr}$ BP to present revealed major climatic phases, especially pertaining to 4,200 yr BP event, MWP (920-440 years BP), LIA (440 160 years BP) and $20^{\text {th }}$ century warming trend (Kotlia and Joshi, 2013). On the other hand, a variance in the intensity of SWM for the past 6,500 $\mathrm{yr} \mathrm{BP}$ based on the isotopic measurements of aragonite gastropods and lake sediments collected from the Kotla Dahar lake located in the northwest Himalaya, was presented by Dixit et al. (2014) (Fig. 3). The data revealed a sharp reduction in the SWM intensity and a peak in the $\mathrm{E} / \mathrm{P}$ ratio in the lake catchment around 4,100 yr BP and suggested that the climate played an important role in the Indus de-urbanization. The 4,200 yr BP aridification event is regarded as one of the most severe climatic changes in the Holocene that affected several Early Bronze age sites.

An overview of available Late PleistoceneHolocene records of the past vegetation vis-a-vis climate based on the latitudinal subdivision of the northeast region was presented by Mehrotra et al., (2014). The study reveals a broad spectrum of the past climate in terms of humid/dry, warm/cold inferred based on the variations of some key pollen or group
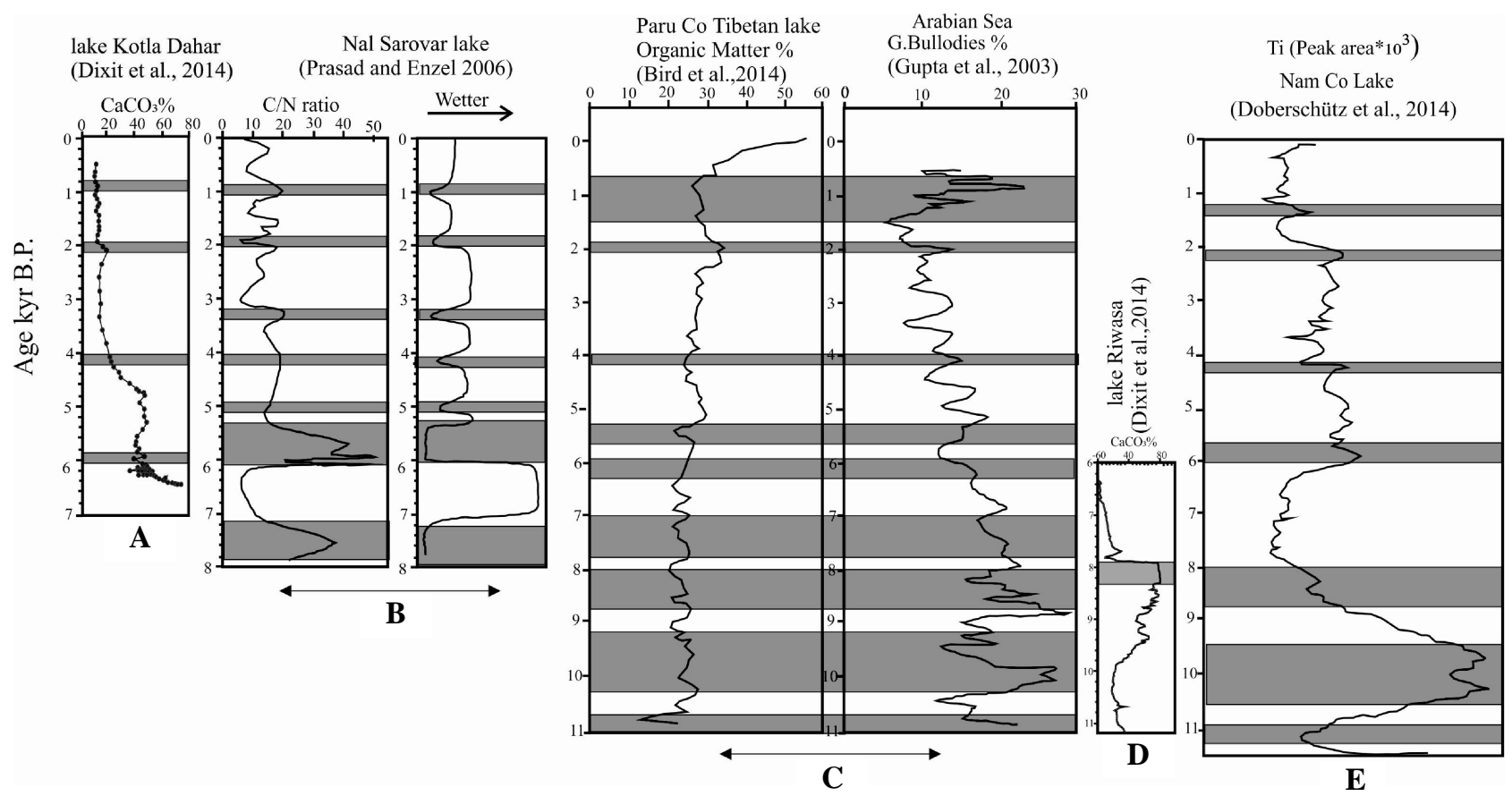

Fig. 3: This panel depicts the vertical variations in (A) $\mathrm{CaCO}_{3} \%$ (Kotla Dahar lake, Dixit 2014), (B) C/N ratio from the Nal Sarovar lake (Prasad and Enzel, 2006), the grey horizontal bar in $\mathrm{C} / \mathrm{N}$ indicates drier events, (C). Variations of Organic Matter in Pro Co Tibetan Lake (Bird et al., 2014) and concentration of the Globigerina bulloides \% from the Arabian Sea (Gupta et al., 2003), (D) Weight percent of calcium carbonate from the paleolake Rewasa sediments versus calibrated ages (Dixit et al., 2014), (E) Nam Co Lake, Tibet (Doberschütz, 2014). The bar denotes climate transition at 2000, 4100, 7100-8000 yr BP and 9400 to 10300 yr BP wetter conditions and periods of high lake stands and or strengthened ISM rainfall 
of pollen taxa depicted diagrammatically, thereby providing a glimpse of spatio-temporal vegetation vis$a$-vis climatic changes using sub-surface samples also. Paleoclimate data based on pollen analysis of the last 3,000 yr BP from the Merbeel Swamp, Dibrugarh District, Assam, exhibits three climatic phases, i.e., relatively cool and dry (3,000-2200 yr BP), the onset of warm (2.2-0.85,900 yr BP), and an increased warm and humid conditions after $800 \mathrm{yr}$ BP (Bera and Dixit 2011). A 1760 yr BP palaeovegetation record from the Mothabeel and Dangrithan reserve forests (Bera et al., 2011) and a pollen analysis from Deosila Swamp, Rangjuli Reserve, Assam, revealed several stages of development and history of Shorea robusta forest and climate shifts since the last $6340 \mathrm{yr} \mathrm{BP}$ (mid Holocene) (Dixit and Bera, 2011). Their data reveal less cool and dry climatic conditions that prevailed during 6340-2970 yr BP followed by warm and humid climate that occurred during 2970 to 1510 BP. An increased SW monsoon and a more warm and humid climate prevailed from 1510 to $540 \mathrm{BP}$; becoming warmer and dry around $540 \mathrm{yr}$ BP. This was probably due to the weakening of the monsoonal rains, and increased anthropogenic activities.

Bhattacharyya et al. (2014) carried out an analysis of vegetation cover and climate change of the Ziro Valley, Arunachal Pradesh since the late Quaternary period. Dixit and Bera (2012a,b,c) showed the development of tropical mixed deciduous forest since 14,120 cal BP using sedimentary record from the Dabaka Swamp in Nagaon District, Assam. Evidence for high energy fluvial activity during 14,120$12,700 \mathrm{yr}$ BP preceded by the occurrence of tropical tree savanna vegetation under cool and dry climate was recorded between 12,700 and 11,600 yr BP. The Younger Dryas is recorded with less cool and dry climate around 11,600-8310 yr BP. Recurrence of intense fluvial activity between $8310-7100 \mathrm{yr} \mathrm{BP}$ and subsequent occurrence of tropical mixed deciduous forest under a warm and humid climate between 7100$1550 \mathrm{yr}$ BP, coinciding with the peak period of the Holocene Climatic Optimum (HCO) was recorded. The tropical mixed deciduous forests continued to prevail under the increased warm and humid climates to $768 \mathrm{yr}$ BP. However, since then the forest began to deteriorate under a warm and relatively dry climatic regime, accelerated by human settlement and forest clearance. Similar human settlement events since 560 BP are also described by Dixit and Bera (2011). A similar trend in the Late Quaternary pollen/vegetation/ climate relationship in and around the Chayagaon swamp, Kamrup District, Western Brahmaputra flood plain of Assam were reported by Bera and Dixit (2011) and Dixit and Bera (2012b).

There are only a few records available based on palynological studies from Meghalaya (Basumatary and Bera 2010 and Basumatary et al., 2014a, b). Detailed pollen studies conducted by Basumatary and Bera (2010) on the Garobadha swam, West Garo Hills, Meghalaya, described the changing vegetation and climate scenario in the region since $1300 \mathrm{yr}$ BP. Three climatic regimes: onset of warm and humid (1300 yr $\mathrm{BP})$, increasing warm and humid ( $752 \mathrm{yr} \mathrm{BP})$, and warm and dry $(\sim 322 \mathrm{yr}$ BP) are recorded. A detailed palynological analysis of the subsurface sediment from Srinagar, southwest Tripura, was carried out by Bhattacharyya et al. (2011) and their studies revealed that the climate during 7000-3000 yr BP in that region was dominantly warm and humid between $6800-\sim 3800$ $\mathrm{yr}$ BP. The probable evidence of the beginning of rice cultivation during the mid-Holocene in the region came from the large-sized grass pollen, that occur since $5700 \mathrm{yr}$ BP.

Ghosh et al. (2015) and Bera et al. (2015) submitted a $\sim 50,000 \mathrm{yr}$ BP record of monsoonal variability in the Darjeeling foothill region of the eastern Himalayas. Pollen, phytoliths and $\delta^{13} \mathrm{C}$ signatures of the soil organic matter from the two fluvial sedimentary sequences of the Darjeeling foothill region, eastern Himalayas portray palaeoclimatic oscillations and their impact on regional plant communities over the last $50,000 \mathrm{yr}$ BP (Ghosh et al., 2015). Quantitative paleoclimate estimation using the coexistence approach on pollen data and other proxies indicates significant oscillations in the precipitation during the late part of MIS 3 (46,400 to $25,900 \mathrm{yr}$ BP), early and middle part of MIS $2(25,900-$ $15,600 \mathrm{yr} \mathrm{BP}$ ) and 5,400 to $3,500 \mathrm{yr}$ BP. Middle to late MIS 3 (ca 46,400-31,000 yr BP) was characterized by a comparatively low monsoonal activity and slightly higher temperature than that during ca 31,000 yr BP onwards. Simultaneous expansion of deciduous trees and chloridoid grasses also imply a drier and warmer phase. Between 31,000 and 22,300 yr BP (late MIS 3 to mid-MIS 2), higher precipitation and a slightly cooler temperature led to an increase in evergreen elements over deciduous taxa and wet-loving panicoid grasses 
over dry-loving chloridoid grasses than earlier. After ca 22,300 yr BP, shrinking of forest cover, expansion of $\mathrm{C} 4$ chloridoid grasses, Asteraceae and Cheno-ams in the vegetation with lowering of temperature and precipitation characterized by the onset of the LGM which continued till 18,300 yr BP. Restoration in the forest cover and increase in the temperature and precipitation regime occurred by the end of LGM. However, since 5,400 to $4,300 \mathrm{yr} \mathrm{BP}$, intense monsoonal activity supported a dense, moist evergreen forest cover that subsequently declined during 4,300 to 3,500 yr BP. A further increase in the deciduous elements and non-arboreals was a consequence of reduced precipitation and higher temperature during this phase.

Although a good data set is available on the late Quaternary paleoclimate from the Himalayan states of India, there is still a dearth of complete quantitative inferences and/or climate reconstruction models based on the present records and climate data and this creates a gap in our understanding of the late Quaternary paleoclimate and vegetation scenarios (Mehrotra et al., 2015). Moreover, there is a paucity of well exposed Quaternary lithosections or lake deposits as the region is often subjected to natural hazards, degradation of vegetation and sediment cover due to anthropogene activities and local urbanisation.

\section{Historical Culture-climate Data from the Ganga Plain}

Ganga Plain, one of the biggest alluvial tracts of the world, is about $1000 \mathrm{~km}$ long and 200-450 km wide. The thickness of the alluvium in the Ganga Plain is about 3000-5000 m towards Himalaya and 200-300 $\mathrm{m}$ towards the Peninsular Plateau. Several tributaries of the Ganges river form a dense network over the Gangetic plain providing a freshwater, which is the main reason of it being one of the most polluted regions of our country. Apart from the river network several, lakes, ponds and low lying areas are spread over that have been used for reconstructing the late Quaternary palaeoclimatic and geoarcheological research. Several sites have been excavated and researched since 20102015 and some of the interesting results are presented below:

Stable oxygen isotope record from the biogenic carbonates analysed from the Rewasa Lake (Haryana) sediments provided the first terrestrial evidence of the $8.2 \mathrm{kyr}$ drying from the Indian subcontinent (Dixit et al., 2014) (Fig. 3) and a history of the Indian Summer Monsoon from<" 11000 to 6000 yr BP. Saxena et al. (2013) identified five wet phases alternating with four dry phases since the past 10,600 yr BP. The phytolith assemblage and Phytolith index of the Lahuradewa lake sediments revealed a dry phase between 5300-4100 yr BP. A multi-proxy study, including pollen, sediment texture and organic/ inorganic carbon analyses of the Chaudhary-Ka-Tal (UP) revealed that around 8470-6422 yr BP grasslands thrived in the region under a warmer and moderatelyhumid climate conditions than today (Saxena et al., 2015). The appearance of cerealia pollen $\sim 7500 \mathrm{yr}$ $\mathrm{BP}$ indicated incipient agrarian practice and the period between 6422-3150 yr BP, a warm and more-humid climate attributed to the strengthening of the SW monsoon was recorded.

Trivedi et al. (2011) studied the lake sediments from Ropan Chhapra Tal, Deoria district (UP) and suggested that between 1350 and $600 \mathrm{yr} \mathrm{BP}$, open grassland vegetation with sparse trees grew under a dry climate with moderate monsoon rainfall. A brief spell of pluvial environment occurred between 600$425 \mathrm{yr} \mathrm{BP}$ with a sharp reduction in trees from $425 \mathrm{yr}$ $\mathrm{BP}$ onwards and the expansion of grasses denoted the onset of relatively drier climate, probably in response to a reduction in the monsoon rainfall. Trivedi et al. (2013) studied the Jalesar Lake (UP) sediments and based on multiproxy data demonstrated that prior to 42,490 until 13,560 yr BP; the Central Ganga Plain supported grassland with scanty trees under a cool and dry climate. The upwarping phase of the Ganga Plain occurred during 13,560-5260 yr BP and that between 5260 and $4760 \mathrm{yr}$ BP the establishment of forest groves under an ameliorating climate thrived. However, around 4760-3260 yr BP, the forest groves diversified and the margins around the lake expanded and acceleration in agricultural practices was observed. Between 3200-1200 yr BP climate became less humid and since $1200 \mathrm{yr}$ BP weak SW monsoon was recorded. Singh et al. (2015) reported a 400 to1200 AD record of the Ropan Chhapra Tal in the Central Ganga Plain using sedimentology, environmental magnetism, and stable isotope of oxygen for SWM variability. Their study revealed that during 400-900 AD, humid to warm, dry conditions favoring stronger SWM seasonality; intense SWM at $\sim 480$ and $\sim 540 \mathrm{AD}$ with flooding around $\sim 700 \mathrm{AD}$ and a weak 
monsoon in 580 and $740 \mathrm{AD}$, with drought at around $500 \mathrm{AD}$ occurred. The multiproxy record suggests that during 900-1200 AD intense summer monsoon was synchronous with the Medieval Warm Period (MWP), whereas after $1200 \mathrm{AD}$, weak monsoon phase coincided with the onset of the Little Ice Age (LIA).

However, the statistical analysis and modeling of Indian Monsoon variability during the past millennium was primarily focused on Medieval climate anomaly (MCA) and the LIA (Polanski et al., 2014). The paleo-hydrological changes depict a dipole pattern between Himalaya and Central India between the LIA and the MCA. Palynological and sedimentological studies also revealed that the LIA was not continuous but interrupted by the short duration of the warmer periods (Achyuthan et al., 2013).

\section{Climate and Precipitation Fluctuations from the Central India}

Various well-dated multi-proxy studies have been carried out in the Himalaya and Central Indian lakes (Mishra et al., 2015; Polanski et al., 2014; Anoop et al., 2013). Chauhan et al. (2013) studied the palynology, texture, mineralogy, geochemistry, and magnetic susceptibility from Padauna Swamp, (MP) and inferred a warm and relatively less humid climate between 8600-7500 yr BP. However, between 7500$6250 \mathrm{yr} \mathrm{BP}$ in response to the onset of a warm and humid climate, the tree-savannahs succeeded by open mixed deciduous forests with the invasion of a few more trees. The period between 6250-2800 yr BP reflected warm and more-humid climate probably due to the invigoration of southwest monsoon. A warm and more-humid climate, including the timely arrival of SW monsoon was observed since $2800 \mathrm{yr}$ BP.

Tripathi et al. (2014) discussed a pollen database synthesis of the palaeovegetation and climate oscillation of western Odisha. Quamar and Bera (2014a, b) described vegetation (modern pollenvegetation) and climate change during the mid and late Holocene in northern Chhattisgarh, central India inferred from pollen records. The Late Holocene paleoclimatic studies based on palynological analysis of Talbehat, Madaura and Dhaura sediments near Jhansi revealed a shift in vegetation depicted in three distinct pollen zones since 4000 years BP to 1400 years BP (Farooqui and Sekhar, 2011) being Moist
Deciduous Forest at around 4000 yrs BP to Mixed Deciduous Forest at around 2000 yrs BP and finally to Dry Deciduous Forest since $\sim 1400$ yrs BP. This study, in particular, showed that the during this time the vegetation succession was in equilibrium with the climatic fluctuations and the agricultural expanse was very limited also due to undulating terrain. When compared to the vegetation succession recorded from the Gangetic plain, it was in contrast, as the Gangetic plain during this period was greatly under the influence of anthropogenic activity with extensive agricultural expanse.

\section{Climate-culture, Historical Records from the Western and Northwestern India}

Prasad et al. (2014) adopted a multi-proxy approach, using palynology, phytoliths, sedimentology, clay mineralogy, carbon isotopes and magnetic mineralogy analyses of Wadhwana (Gujarat) lake sediments to determine the mid-Holocene climatic fluctuations, and surmised that the urbanization in the Harappan civilization in northwest India was coincident with the initial phase of drastic decline in the rainfall during mid-Holocene. The emergence of cultural complexity of Harappan civilization was an initial adaptation to the earliest phase of environmental deterioration during this period. The subsequent decline of the Harappan civilization is probably linked to the changing seasonality pattern and excessively dry climate of later phase ( 4200-4255 yr BP) of the mid-Holocene. Raj et al. (2015) based on a multiproxy study of the Pariyaj Lake archive, studied the Holocene climatic fluctuations of the Gujarat alluvial Plains.

Coastal archaeological sites serve as potential archives of past climate-culture and vegetation relationship, responding to the relative sea level changes during the Holocene. Most of the Harappan dwellers along the coastal region largely depended on perennial or monsoon-driven river systems for fresh water requirements for the agriculture based sustenance. The period since $4000 \mathrm{yrs}$ BP witnessed climatic amelioration from warm and humid (high precipitation) to dry and arid (low precipitation). Consequences of climate change evolved the vegetation from evergreen moist deciduous to dry deciduous as number of dry months per annum increased. The palynological results from Bet Dwarka, Bokhira (Porbander) revealed absence of vegetation, 
although fresh water thecamoebians and few marine palynomorphs indicated the relative extent of fresh water and marine water incursion (Farooqui and Gaur, 2013). Results from the Kodinar (Kaj and Kanjetar) revealed a significant abundance of evergreen and moist deciduous vegetation around $4000 \mathrm{yr} \mathrm{BP}$, which gradually declined and was replaced by dry deciduous vegetation by around 2000 yrs. BP (Farooqui et al., 2013). The present day hinterland vegetation in these areas and adjacent northeast Gir Forest is largely represented by dry deciduous plant taxa except for mangrove in coastal areas. The overall results show that the dry and arid climate reached its climax in Bokhira and Porbander (22"-22' 30' N Latitude) around 4000 yr BP while in Kodinar (21"-21' 30' N Latitude) it reached its climax around 2000 yrs. BP. Thus, the climatic climax of dry and arid conditions shifted from North to the southern region of Saurashtra. The fragments of ancient potteries and other artefacts recovered from the lower sediment layers provide evidences of Sorath-Harappan colonization in the vicinity which was not an urban site.

The abundant cyanobacterium remains, low terrigeneous organic matter, aquatic pollen and low thecamoebians in lower sediment layers point to low precipitation and arid climatic conditions $\sim 2000 \mathrm{BC}$ (Farooqui et al., 2013). During this period the dominance of evergreen and moist deciduous arboreals from both the sites does not show equilibrium with the prevailing dry/arid climate and therefore, the pollen assemblage here represents the remnants of wetter middle Holocene vegetation in the region. Phytoliths of drought tolerant summer season crops also reflects here changes made in the agricultural strategy by the Harappans in response to climate (Enzel et al., 1996; Giosan et al., 2012; Ponton, et al., 2012; Rashid et al., 2011; Madella and Dorian, 2006; Possehl 2002; Staubwasser et al., 2003). The increase in deciduous arboreal pollen since the last 2000 years represents equilibrium with the dry/arid climate (Madella and Dorian, 2006; Farooqui et al., 2013). But, enhanced limnic conditions recorded due to the occurrence of thecamoebians during this period are attributed to changes in wetland configuration induced by hydrostatic changes in the river mouth. This was also largely defined by the dynamics of sediment deposition through rain-fed rivers/streams in the region (Farooqui et al., 2013).
Ponton et al. (2012) reconstructed the Holocene paleoclimate in the core monsoon zone (CMZ) of the Indian peninsula using a sediment core recovered offshore from the mouth of Godavari River. Carbon isotopes of sedimentary leaf waxes proved to be a useful tool for an integrated and regionally extensive record of the flora in the CMZ and they documented a gradual increase in aridity-adapted vegetation from $\sim 4,000$ until 1,700 years ago followed by the persistence of aridity-adapted plants after that. The oxygen isotopic composition of planktonic foraminifer Globigerinoides ruber detected an unprecedented high salinity events in the Bay of Bengal over the last 3,000 years, and especially after 1,700 years ago, which indicated that the $\mathrm{CMZ}$ aridification intensified in the late Holocene through a series of sub-millennial dry episodes. Cultural changes occurred across the Indian subcontinent as the climate became more arid after $<4,000$ years. Sedentary agriculture took hold in the drying central and southern India, while the urban Harappan civilization collapsed in the already arid Indus basin. The establishment of a more variable hydroclimate over the last ca. 1,700 years may have led to the rapid proliferation of water-conservation technology in south India (Giosan et al., 2012 and Ponton et al., 2012).

\section{Late Quaternary Records from the Southern India}

The lake sediment retrieved from southern Indian lakes has largely been studied for reconstructing the fluctuations in the intensity of the SWM. The late Quaternary studies of the Vembanad Lake peat deposits indicated arid climate prior to $40,000 \mathrm{yrs}$ BP humid climate. Detailed pollen studies revealed the existence of mangrove vegetation and evergreen forest, suggesting a humid climate and high intensity of SWM during that period (Nair et al., 2010; Padmalal et al., 2014; Nair et al., 2014). The occurrence of a peat sequence in the sediments in the low-lying area around the Vembanad Lake supported by radiocarbon dates showed that their formation was from the submerged coastal forests, especially of mangrove vegetation (Nair et al., 2014). The palynological study of the late Quaternary evolution of Ashtamudi-Sasthamkotta lake systems of Kerala reveals that a marine transgression occurred at $\sim 6000 \mathrm{yrs}$ BP coupled with heavy rainfall in the hinterlands that was responsible for faster sedimentation in the region (Nair et al., 2010). 


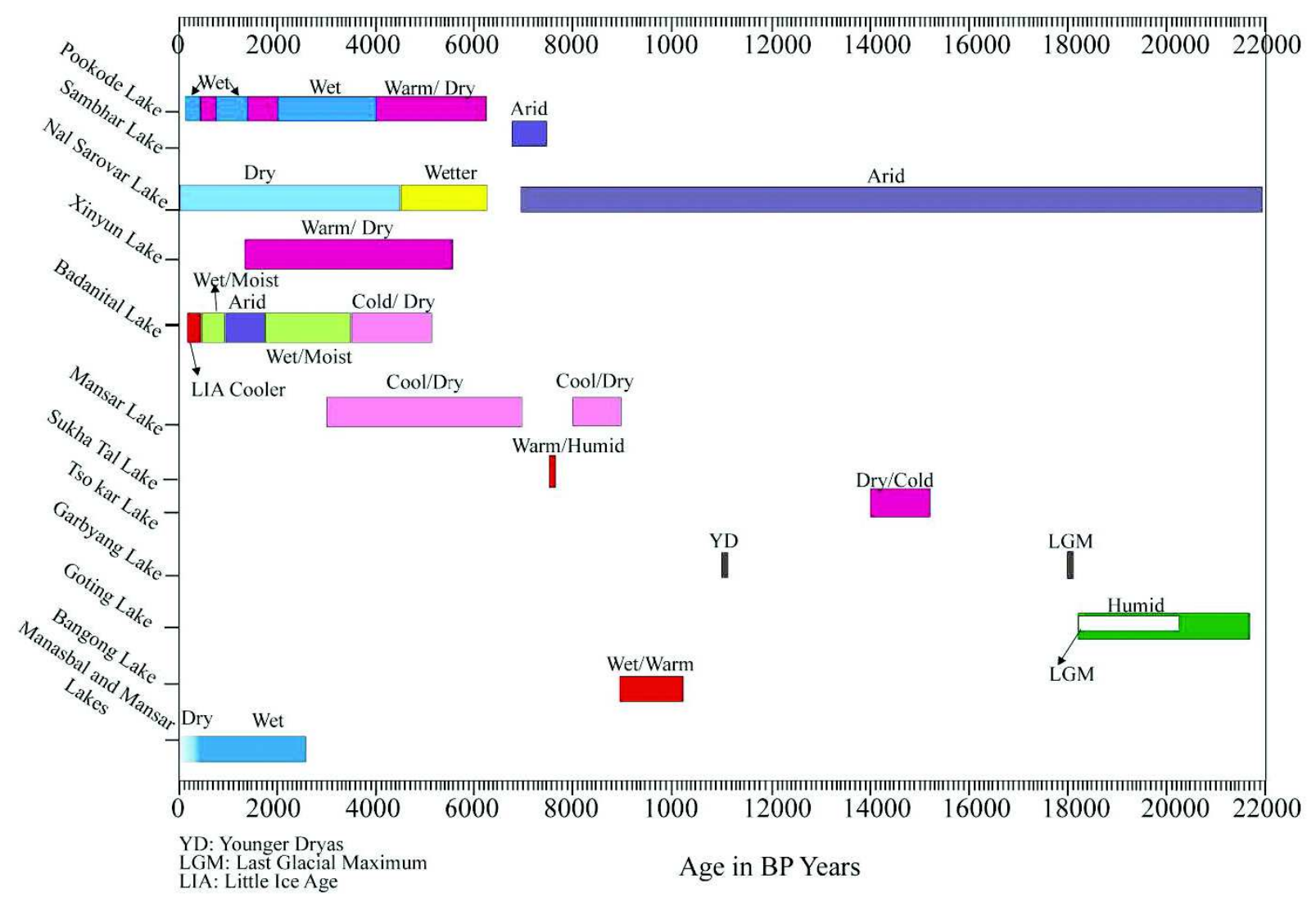

Fig. 4: Compilation of the late Quaternary to Holocene paleoclimate reconstructed from different lakes adopting multi proxy analyses

The recent studies in the Pookode Lake, Kerala, analyzing the multi proxies, such as sediment texture, radiocarbon dating, phytolith, diatoms, spores and pollen revealed a change in the hydrological conditions as well as shallow of the lake since the last $6000 \mathrm{yr}$ BP (Veena et al., 2014). The lake sediments have preserved the evidence of the Medieval Warm Period (MWP) and the Little Ice Age (LIA). Textural analysis, geochemistry and palynology revealed the occurrence of a warm and dry period that prevailed during 6,200 to $420 \mathrm{yr} \mathrm{BP}$ and were interrupted by the wet phases between $~ 3,900$ to $1,900,1,400$ to 760, 420 to $140 \mathrm{yr}$ BP due to strengthening of SWM, rise of water level, and the expansion of the Pookode lake margin (Veena et al., 2014; Nair et al., 2014) (Fig. 4).

Further corroborating the data of the Pookode Lake; a detailed limnology of the Kukkal lake sediments revealed a continuous sediment record since the Early Holocene to the present (9000 yrs BP to present). The present lake situated at an elevation of $\sim 1887$ m.a.s.l., is a small basin that appears to have alternated between lacustrine and wetland deposition. Climate proxies including sediment texture, TOC, TN, $\mathrm{C} / \mathrm{N}$, pollen and geochemical composition indicate a steady progression to wetter conditions, with two stepwise changes at about 8000 , and between 3200 and 1800 years BP. The change at $8000 \mathrm{BP}$ appears to correspond to a brief (100-150 years) dry spell recorded elsewhere in India. The change at 3200$1800 \mathrm{BP}$ consisted in a rapid intensification of the southwest monsoon, and may correlate with the initiation of the Roman Warm Period. There is no clear evidence of changes at the times of the Medieval Warm Period and the Little Ice Age. The $\mathrm{C} / \mathrm{N}$ ratio of the sediments ranges from 14.02 to 8.31 indicating that the organic matter originated from a mixture of lacustrine algae and vascular plants. Chemical weathering indices (CIA, CIW and PIA) are consistent with extreme silicate. Pollen data show an evolution from savanna vegetation prior to about 8000 years BP, followed by grassland with palms, the appearance of spore-bearing plants just prior to 3200 
years BP, and the reestablishment of 'Shola' forest between 3200 and about 1800 BP (Vijayraj et al., 2016).

Similarly, another sediment core raised from the Parson's valley, Ooty, was Radiocarbon dated. The ages range from $22,470-1240 \mathrm{yr} \mathrm{BP}$. The $\mathrm{C} / \mathrm{N}$ value varies from $10.30(21,810 \mathrm{yr} \mathrm{BP})$ to $22.45(1240 \mathrm{yr}$ $\mathrm{BP})$ reflecting mixed (terrestrial and aquatic) origins of the organic carbon since the late Marine Isotope Stage 3. The sediments are mostly silt (84\%), with minor amounts of clay and sandy silts. The $\delta^{13} \mathrm{C}$ values exhibited major shifts from -17.6 to $-14.0 \%$ around $22,470 \mathrm{yr}$ BP to $19,100 \mathrm{yr}$ BP and $-16.9 \%$ o to $-3.8 \%$ o around 1240 to $820 \mathrm{yr} \mathrm{BP}$ is reflecting drier conditions due to decrease in the intensity of both the monsoons (Priyanka et al., 2016). A shift of $\delta^{13} \mathrm{C}$ from $-14.7 \%$ o to $-16.5 \%$ o (around 15,900 to $2820 \mathrm{yr} \mathrm{BP}$ ) points to ameliorate monsoon conditions. Absence of coarser sediments indicates reduced terrestrial flux due to the decrease in monsoonal runoff, dry climate or thick vegetation canopy around the lake since $19,100 \mathrm{yr}$ BP (Priyanka et al., 2016).

Basavaiah et al. (2015) employed mineral magnetic, geochemical, and textural parameters to elucidate the climate and sea level change signatures from Kolleru lake sediments representing the interdeltaic part of the Krishna-Godavari sedimentary basin (KG basin). The various mineral magnetic parameters, $\mathrm{c}$ and S-ratio along with major elemental concentrations of $\mathrm{Ti}, \mathrm{Al}, \mathrm{Fe}$ and $\mathrm{Zr}$ show signatures of an arid event before 10,000 yr B, between 9,000$8,000 \mathrm{yr}$ BP periods and during the last 5,500 yr BP. The overall climate of warm and humid type was inferred from 10,000 to 9,000 yr BP, which correlates with Early Holocene Optima and 6,000 to 5,500 yr BP of Middle Holocene. The presence of evaporite crystals in the lower layers of the sediment core corroborated by mineral magnetic and geochemical proxies indicates sub-aerially weathered facies during the arid Late Pleistocene. Similarly, the peat layers rich in mangrove pollen indicate sea level changes between 10,000 yr BP and 6,000 yr BP. The subsurface position of the Pleistocene weathered layer and the Holocene peat layer suggests tectonic subsidence of the area, which is situated over the basement graben, known as Gudiwada sub-basin.

Recent work on the Vellayani lake, carried out by Veena et al. (2015), suggested that the humans have continuously changed the landscape and vegetation cover of the earth, including deserts and lake margins. Vellayani Lake, Kerala, is being severely affected by human activity in the catchment basin. Population increase, leading to increased demand for agricultural land and water, is driving a positive feedback loop resulting in the accelerating siltation of the lake and lowering of water levels. A $145 \mathrm{~cm}$ sediment core has represented deposition since 3000 years BP, but at least half of the sediment has been deposited since $1650 \mathrm{AD}$, possibly since $1950 \mathrm{AD}$. The sediment stratigraphy was disturbed, most likely by slumping since 1970, of an unstable sediment accumulation near the lake margin. The disturbance precludes detailed interpretation of paleoenvironmental proxies, textural variation, chemical weathering index, pollen and phytolith assemblages. The proxies provided evidence of drier climate up to 3000 years BP, and wetter conditions at about 1210 years BP. Low frequency of phytoliths morph types indicated reduction in vegetation cover and a significant increase in grassland since 2300 yrs BP due to climate warming, weakened southwest monsoon, deforestation reclamation of the lake margins for intensive agricultural practices. Occurrence of diatoms and sponge spicules indicated shallowing of the lake from 2300 yrs BP onwards. Occurrence of charcoal pieces post 3,000 yrs BP represented human impact along the lake margin. Integration of all the results showed that the Vellayani Lake contracted because of a weakened Indian southwest monsoon since $3000 \mathrm{yrs} \mathrm{BP}$, intense human impact in the form of deforestation, irrigation and agricultural practices.

\section{Climate Induced Relative Sea Level Fluctuations from the Southern Coastal Zone}

A complex interplay of riverine and marine processes has shaped the deltaic areas of the Indian peninsula in space and time. Most of rivers/streams that join the Bay of Bengal in the east and the Arabian Sea in the west traverses a long distance and are monsoon driven. Therefore, the palynological succession reconstructed from sediments deposited in coastal wetlands largely depict the changes in Indian monsoon. In India, the coastal wetlands sustain millions of people and are more vulnerable to the effects of a rise in Relative Sea level (RSL) and changes in marine ecosystems. The sediment depositional environments varying from lacustrine to fluvial, fluvio-marine to 
purely marine depends upon the geomorphology and related shoreline fluctuations. The deltaic dynamism is largely influenced by monsoon driven active channels, tectonic nature of the basin, sea-level changes, relief of the drainage basin and climate. The analysis of delta building process through time and the dynamics of the coastal wetlands are essential to predict the future changes, especially in context of sea level rise and coastal erosion. Land subsidence in modern coastal or deltaic plains is a common process. Sea water invasion and loss of deltaic land have been reported in Krishna-Godavari delta (Nageshwara Rao et al., 2013; Farooqui, 2013; Ranjana and Farooqui 2015; Farooqui et al., 2016).

The consequences of climate change and land subsidence are often related to sea level rise/fall. Mangroves, its extinction and migration through time was assessed through palynological studies in two sediment cores from Kanuru (500 cm deep) and Machilipatnam (118 cm deep), Krishna delta, India. Four Units were identified on the basis of marine/ terrestrial palynomorphs. In Unit 1, the marine palynomorphs indicate palaeoshoreline in Kanuru from 8420-8300 yr BP, which is now $\sim 4-5 \mathrm{kms}$ inland from the present shoreline. After a short span a retreat in sea level took place between 8300-7040 yr BP. Subsequently, about 3-4 short-term intermittent rise/ fall in RSL were recorded in Unit 2 between 7040 and $3980 \mathrm{yr}$ BP in Kanuru and between 5225-3240 yr BP in Machilipatnam. The Unit 3 is characterized by non-estuarine sediment deposition since 3920-240 yr BP in Kanuru and since 3240-950 yr BP in Machilipatnam. The Unit 4 reveals a rise in RSL in both the studied sites which began much earlier in Machilipatnam than in Kanuru. Loss of mangrove diversity and dominance of salt tolerant mangroves was recorded in Unit 4. Results indicate climate induced RSL fluctuations highlighting the event of 8200 yr BP from Kanuru site and duration of the intermittent rise/fall of RSL during the Middle Holocene transgression. The rate of sea level rise during the period was not continuous but interrupted by 3-4 retreats (Farooqui, 2013) suggesting neotectonics. Overall the results reveal that Middle Holocene warming and sea level rise was not continuous but fluctuated with intermittent short duration before the weakening of monsoon was set in during the late Holocene ( 3000-2500 yr BP).
Similar trends in climate induced relative sea level changes were recorded from the Pichavaram estuary, Tamil Nadu. The pollen and sedimentology results reveal a climate shift from warm and humid with the strengthened monsoon (3630-3190 BP) to dry and arid ( 2750-760 BP). Since the last millennium ( 760 BP), Pichavaram estuary has been influenced by a similar cyclicity but with a less wet and humid climate due to weakened northeast monsoon conditions. The ecological changes, in turn, affect the relative sea level rise and fall, which is reflected by the variability/extinction of freshwater and marine palynomorphs (Srivastava et al., 2013). The palynological reconstruction of sediments deposited between $(2,500-4,000 \mathrm{yr} \mathrm{BP})$ reveals fluvio-marine deposition and a good percentage of diverse mangrove species, indicating comparatively strengthened monsoon condition (warm and humid climate) along with adequate seawater ingression through tidal inlets which favoured the estuarine ecosystem. During this period the stability of relative sea level is recorded due to the consistency recorded in the mangrove pollen percentage and other terrestrial and marine palynomorphs (Srivastava et al., 2011, 2012, 2013; Srivastava and Farooqui, 2013). The overall results from coastal wetland archives also conform with the records of climate changes documented on land in different parts of India.

\section{Climate Induced Vegetation Changes During the Late Pleistocene: Evidences from the West Coast}

Neogene rain forest flora recorded earlier from the Varkala Formation and the present record of its existence since MIS-6 in the region indicate that the monsoon circulation over the southern India was similar since the Middle Miocene Climate Optimum and the flora in the South-Western Ghats is a fossil ecosystem and a relic of the Tertiary period (Farooqui et al., 2014).

The southwestern Ghats region of the Indian Peninsula is unique for its extant endemic rainforest flora supported by high rainfall throughout the year. The record of tropical rainforest corresponding to the dynamic series of Pleistocene interglacial/glacial cycles is poorly known from peninsular India. The palynological study of organic matter (OM) deposits (>40,000 yr BP) in two well sections (Chaganachery, Kerala) from the Indian Peninsula (west coast) were 
carried out. Arich archive of tropical rainforest pollen/ spores and marine dinoflagellate cysts indicates anoxic fluvio-marine/estuarine deposition environments during warmer climate with an intensified Asian monsoon. The geochemical fingerprinting of glass shards indicates the presence of Youngest Toba (YTT) ash of $\sim 74,000 \mathrm{yr}$ BP from northern Sumatra, and therefore establishes a time-controlled stratigraphy. The depositional time period of the $\mathrm{OM}$ is related to the sea level highstand of Marine Isotope Stage 5.1 ( 80,000 yr BP) which was the host to the YTT shards. The Late Quaternary pollen/spores diversity suggests that the modern climatic conditions in the southwestern Ghats have facilitated the conservation of moist evergreen rainforest and dry/moist deciduous forest. The pollen grains show its lineage with the extant flora and some of the fossil pollen recorded during the mesic Tertiary period from the Indian peninsula. Thus, it appears that the tropical rainforest survived here as 'Plant Refugia' in xeric (glacial) Quaternary periods, perhaps as riparian vegetation, and was rejuvenated during the Holocene as modern extant flora (Farooqui et al., 2010).

Further, a palynochronological study of a 552 $\mathrm{cm}$ deep sediment core from the southeastern Arabian Sea covered a time span of $\sim 1,40,000 \mathrm{yr}$ BP. The age estimate is based on oxygen isotopic data of planktic foraminifera. Six zones were identified on the basis of palynology covering partially MIS- 6 and MIS-5 to MIS-1 (Marine Isotope Stages). The interglacial period (MIS-5) reveals high rate of sedimentation corresponding to the high percentage of terrestrial rain forest pollen. The palynological study reveals highstand and intense rain forest vegetation during MIS 5a, which corresponds to the similar earlier records of estuarine ecosystem on land in Kerala. The relative sea level rise and fall since $\sim 1,40,000 \mathrm{yr}$ $\mathrm{BP}$ have been inferred through quantitative estimate of marine versus terrestrial palynomorphs. The terrigenous non-pollen forms comprised abundant Neogene extinct nanoplanktons (Discoaster spp.) until MIS-3 and was transported from the Varkala Formation (highlands of the Kerala coast). The pollen assemblage is comparable to the present day flora in Kerala therefore, the provenance of pollen recorded in the studied core is Western Ghats of India. High percentage of planktic foraminifera and dinoflagellate cysts throughout the core indicates high productivity that suggests upwelling induced by seasonal reversals in the monsoon winds even during the glacial periods. Botryococcus remains, and poaceous leaf cuticles dominated by the Pooideae group in the marine realm also point towards active winter monsoon. Considerable fragmentation of rain forest took place post 74,000 yr BP and during the LGM as the sea retreated to its maximum which resulted into the vast exposure of land favoring the expanse of grassland with pockets of rainforest "plant refugia" on land.

Lastly, substantial records of modern pollen studies and vegetation distribution in terms of surface pollen records are available (Basumatary and Bera, 2010; Bera and Dixit, 2011; Dixit and Bera, 2011, 2012a, b, c; Bera, et al., 2011; Basumatary and Bera, 2012; Achyuthan et al., 2013). However, for the reconstruction of paleoenvironments, there is a need for the detailed quantification of the surface pollen data, modern pollen rain which represent the modern climate. These data supplemented by fossil pollen records can be calibrated to develop a transfer function model (Guiot, 2011) which then can be used to quantitatively reconstruct paleoclimates with a greater degree of confidence. There is a need for such climatic reconstruction, which has not yet been attempted.

\section{Conclusions}

Several studies through different proxies show the sensitivity of biotic forms which correspond to more or less well defined climatic fluctuations in most of the studied areas in India. The duration of the climatic events and its intensity, however, varied from region to region depending on the local landscape and geographical location. Following points emerge from this review study based on the reconstruction of southwest monsoon and climatic conditions since the late Quaternary depicted using multi-proxy studies involving sedimentology, geochemistry, pollen/spores, phytolith, etc.

1. It is noted that through the late Quaternary to the Holocene period the intensity of SWM declined, but was interspersed with short intervals of high rainfall. This allowed the margins of the lake to shrink, but increased during the short periods of high rainfall. There was a gradual vegetation evolution by a reduction in the percentage of evergreen forest to semievergreen or to mixed moist deciduous forest 
and these changes occurred in most of the areas in the Indian sub-continent.

2. Moderate to low rainfall areas in India reveal a drastic change from moist deciduous forest to dry deciduous forest since the last 5000 to 4000 yr BP. These changes are interrelated to three main factors such as the influence of extratropical Westerlies in western and central Himalayas, the summer temperature gradient between Bay of Bengal and Indian subcontinent along with Indian East Asian Monsoon affecting the eastern Himalayas. The central India is affected by summer sea surface temperatures of the Arabian sea influenced by Indo-Pacific warm pool that modulates the Indian monsoon.

3. The lake records irrespective region in India, few of them hold signature of the 8200 solar insolation, 4200 arid environment, 3800 warm and dry periods, MWP and LIA events. The overall results from coastal wetland archives also conform to the records of climate changes documented on land in different parts of India.

\section{References}

Achyuthan H, Farooqui A, Eastoe C, Ramesh R, Devi M and Ganesh P P (2013) A five century long limnological and environmental record from northeastern India. In: (Ed. Kotlia B S) Holocene- Perspectives, Environmental Dynamics and Impact Events Nova Science Publishers Inc 129-143

Anoop A, Prasad S, Krishnan R, Naumann R and Dulski P (2013) Intensified monsoon and spatiotemporal changes in precipitation patterns in the NW Himalaya during the early-mid Holocene in Quat Internat 313-314 74-84

Atahan-E S and Aspuru G A (Eds.) (2014) Prediction and Calculation of Crystal Structures Methods and Applications Topics in Curr Chemistry 345 Doi: 10.1007/ 978-3-319-05774-3

Basavaiah N, Mahesh Babu J L V, Gawali P B, Naga Kumar K Ch V, Demudu G, Siddharth Prizomwala P, Hanamgond P T and Nageswara Rao K (2015) Late Quaternary environmental and sea level changes from Kolleru Lake, SE India: Inferences from mineral magnetic, geochemical and textural analyses in Quat Internat 371 197-208

Basumatary S K and Bera S K (2010) Development of vegetation
Our results indicate that the combination of proxy and model data leads to an improved understanding of the paleo-climate. Proxy data are used to validate model simulations of climates of the past. The model data can then be analyzed to investigate the mechanism behind the changes.

\section{Acknowledgements}

In this review, we have considered all the published data till date, if we have missed any, this was inadvertent. We acknowledge all the researchers who have published their work. We are grateful to Prof. A.K. Singhvi, PRL, Ahmedabad, for inviting us to write a review on the reconstruction of Late Quaternary to Holocene past climate based on lake sediments. Gopal $\mathrm{V}$ and Lone A thank the UGC, New Delhi for the Dr DS Kothari Postdoctoral Fellowship (No.F. 4-2/ 2006(BSR)/ES/14-15/0020) and Anna Centenary Research Fellwoship, Anna University, Chennai, respectively. We thank the reviewers for their encouraging comments that helped in the presentation of the data and the manuscript.

and climate change in West Garo Hills since late Holocene: pollen sequence and anthropogenic impact in J Indian Bot Soc 89 143-1148

Basumatary S K and Bera S K (2014a) Modern pollen record on Bat Guano deposit from Siju Cave and its implication to palaeoecological study in south Garo hills of Meghalaya, India in J Cave Karst Studies 76 173-183

Basumatary S K, Tripathi S, Bera S K and Kumar S (2014b) Pollen morphology of Nepenthes khasiana Hook. F. (Nepenthaceae): An endemic insectivorous plant of India in Palynol 38 324-333

Basumatary S K, Tripathi S, Bera S K, Nautiyal C M, Devi N and Sarma G C (2014c) Late Pleistocene palaeoclimate based on vegetation of the Eastern Himalayan foothills in the Indo-Burma in Palynol DOI: http://dx.doi.org/10.1080/ 01916122.2014 .945665

Basumatary S K and Bera S K (2012) Vegetation succession and climate change in Western Garo hills, Meghalaya, India since 11,643 year BP: a palynological record in Inter Jour Earth Sci Eng $\mathbf{5}$ 748-758

Bera S K and Dixit S (2011) Pollen analysis of Late Holocene lacustrine sediment from Jeypore reseve forest, Dibrugarh, 
Assam in Geological process and climate change 85-94 Macmillan Publishers India Ltd

Bera S K, Dixit, S, Saini D C and Sekar B (2011) Impact of metal concentration and pollen preservation in Copper and Manganese ore rich soil from Balaghat District, Madhya Pradesh: Mineral indicator plants and fungal remains in Internat J of Earth Sci and Engineering 4 719-724

Bera G C, Farahmand P, Cavailloles F and Lussey C L (2015) ${ }^{18}$ Fluorine fluorodeoxyglucose positron emission tomography diagnosis of an aortic thoracic prosthesis infection by slow-growing bacteria in Int J Case Rep Images 6 381-383

Bhattacharyya A, Mehrotra N, Shah S K, Basavaiah N, Chaudhary V and Singh I B (2014) Analysis of vegetation and climate change during Late Pleistocene from Ziro Valley, Arunachal Pradesh, Eastern Himalaya Region in Quat Sci Rev 101 $111-123$

Bhattacharyya A, Ranhotra P S and Gergan J T (2011) Vegetation vis-a-vis Climate and Glacierhistory during 12,400 to 5400 yr BP from Dokriani valley, Garhwal Himalaya, India in $J$ of Geol Soc India 77 401-408

Bird B W, Polisar P J, Lei Y, Thompson L G, Yao T, Finney B P, Bain D J, Pompeani D P and Steinman B A (2014) A Tibetan lake sediment record of Holocene Indian summer monsoon variability in Earth Planet Sci Lett 399 92-102

Bogotá R G, Groot M H M, Hooghiemstra H, Lourens L J, Linden M V D and Berrio J C (2011) Rapid climate change from north Andean Lake Fúquene pollen records driven by obliquity implications for a basin-wide biostratigraphic zonation for the last 284 ka Quat Sci Rev 30 3321-3337

Brauer A, Günter C, Johnsen S J and Negendank J F W (2000) Land-ice teleconnections of cold climatic periods during the last Glacial/Interglacial transition in Clim Dyn 16229 239

Brock D W and Wikler D (2006) "Ethical Issues in Resource Allocation, Research, and New Product Development." Disease Control Priorities in Developing Countries. 2nd ed Jamison D T, Breman J G and Measham A R (eds), Washington (DC): World Bank

Caballero M, Vazquez G, Lozano-Garcia S, Rodriguez A, SosaNajera S, Ruiz-Fernandez AC, Ortega B, 2006. Present limnological conditions and recent (ca. 340 yr) palaeolimnology of a tropical lake in the Sierra de Los Tuxtlas, Eastern Mexico in J Paleolimnol 35 83-97

Cardoso S J, Enrich P A, Pace M L and Roland F (2014) Do models of organic carbon mineralization extrapolate to warmer tropical sediments? Limnol Oceanogr 59 48-54

Chaudhry P, Sharma M P, Bhargave R, Kumar S and Dadhwal P
J S (2013) Water quality assessment of Sukhna lake of Chandigarh city of India in Hydro Nepal 12 26-31

Chauhan M S, Sharma A, Phartiyal B and Kumar K (2013) Holocene vegetation and climatic variations in Central India: A study based on multiproxy evidences in $J$ of Asian Earth Sci 77 45-58

Das B K, Gaye B and Malik M A (2010) Biogeochemistry and paleoclimate variability during the Holocene: a record from Mansar Lake, Lesser Himalaya in Environ Earth Sci 61 $565-574$

deMenocal P, Oritz J, Guilderson T, Adkins J, Sarnthein M, Baker L and Yarusinsky, M (2000) Abrupt onset and termination of the African humid period. Rapid climate responses to gradual insolation forcing in Quat Sci Rev 19 347-361

Dixit S and Bera S K (2011) Mid-Holocene Vegetation and Climatic variability in Tropical deciduous Sal (Shorea robusta) forest of Lower Brahmaputra valley, Assam, Northeast India in $J$ of the Geol Soc India 77 419-432

Dixit S and Bera S K (2012a) Holocene climatic fluctuations from Lower Brahmaputra flood plain of Assam, northeast India J Earth Sys Sci 121 135-147

Dixit S and Bera S K (2012b) Pollen rain studies in wetland environ of Assam, Northeast India, to interpret present and past vegetation in Internat $J$ of Earth Sci and Engineering 5 739-747

Dixit S and Bera S K (2012c) Diatom assemblage from surface sediments of lower Assam floodplain, Northeast India in $J$ of the Indian Botan Soc 91 310-316

Dixit Y, Hodell D A and Petrie C A (2014) Abrupt weakening of the summer monsoon in northwest India $\sim 4100$ ago in Geol 42 339-342

Doberschütz S, Frenzel P, Haberzettl T, Kasper T, Wang J, Zhu L, Daut G, Schwalb A and Mausbacher R (2014) Monsoonal forcing of Holocene paleo- environmental change on the central Tibetan Plateau inferred using a sediment record from Lake Nam Co (Xizang, China) in J Paleolimnol 51 253-266

Dressler M, Selig U, Dorfler W, Adler S, Schubert H and Hubener T (2006) Environmental changes and the Migration Period in northern Germany as reflected in the sediments of Lake Dudinghausen Quat Res 66 25-37

Eggermont H, Russell J and Verschuren D (2007) response of Rwenzori (Uganda-DR Congo) Glaciers and mountain lake ecosystems to climate change: Past, present Future in American Geophysical Union, Fall meeting 2007, abstract\#GC32A-07

Enzel Y R, Amit N, Porat E, Zilberman and Harrison B J (1996) 
Estimating the ages of fault scarps in the Arava, Israel in Tectonophysics 253 305-317

Fagel N and Boss X (2008) Clay mineral record in Lake Baikal sediments: the Holocene and Late Glacial transition in Palaeogeog Palaeoclimatol Palaeoecol 259 230-243

Fagel N and Mackay A W (2008) Weathering in the Lake Baikal watershed during the Kazantsevo (Emian) interglacial: evidence from the lacustrine clay record in Palaeogeog Palaeoclimatol Palaeoecol 259 244-257

Farooqui A and Gaur A S (2013) Climate Induced Vegetational Evolution: Palynological and Thecamoebian Study from Coastal Archaeological Sites, Saurashtra in Proc $8^{\text {th }}$ National Conference on Marine Archaeology at Goa In: Marine Archaeology of India, NIO Publication 97-106

Farooqui A and Sekhar B (2011) Climate change and vegetation succession in Lalitpur area, Uttar Pradesh (India) during late Holocene in Tropical Ecol 52 69-77

Farooqui A, Gaur A S and Prasad V (2013) Climate, vegetation and ecology during Harappan Period: Excavations at Kanjetar and Kaj, Mid-Saurashtra coast, Gujarat in $J$ Archaeol Sci 40 2631-2647

Farooqui A, Pattan J N, Parthiban G, Srivastava J and Ranjana (2014) Palynological record of tropical rainforest vegetation and sea level fluctuations since $140 \mathrm{ka}$ from sediment core, south-eastern Arabian Sea in Palaeogeog Palaeoclimat Palaeoecol 411 95-109

Farooqui A, Ranjana and Nautiyal C M (2016) Deltaic land subsidence and sea level fluctuations along the east coast of 1 India since 8ka: A palynological study in Holocene (in press)

Farooqui A, Ray J G, Farooqui S A, Tiwari R K and Khan Z A (2010) Tropical rainforest vegetation, climate and sea level during the Pleistocene in Kerala, India in Quat Internat $2132-11$

Farooqui A (2013) A glimpse of palynological succession from India: vegetation, climate and anthropogeny since Middle Holocene In: (Ed.: Kotlia B S) Holocene Perspectives, Environmental Dynamics and Impact Events Nova Science Publishers Inc 7388

Fleitmann D, Burns S J, Muderlsee M, Neff U, Kramers J, Mangini A and Matter A (2003) Holocene forcing of the Indian monsoon recorded in a stalagmite from Southern Oman in Science 300 1737-1739

Garçon M, Chauvel C, Chapron E, Fain X, Lin M F, Campillo S, Bureau S, Desmet M, Bailly-Maître M C and Charlet L (2012) Silver and lead in high-altitude lake sediments Proxies for climate changes and human activities in App Geochem 27 760-773
Gasse F (2000) Hydrological changes in the African tropics since the Last Glacial Maximum in Quat Sci Rev 19 189-211

Gasse F, Fontes J C, van Campo E and Wei K (1996) Holocene environmental changes in Bangong Co basin (Westerbn Tibet). 4. Discussison and conclusions in Paleogeog Paleoclimat Paleoecol 120 79-92

Gharibreza M R, Yusoff I, Raj J K, Othman Z, Wan Zakaria W $\mathrm{T}$ and Ashraff M A (2012) Historical variations of Bera Lake (Malaysia) sediments geochemistry using radioisotopes and sediment quality indices in J Radioanal Nucl Chem 295 1715-1730

Ghosh R, Bera S, Sarkar A, Dipak Kumar Paruya and Yi-Feng Yao Cheng-Sen Li (2015) A 50 ka record of monsoonal variability in the Darjeeling foothill region, eastern Himalayas in Quat Sci Rev 114 100-115

Giosan L (2012) Fluvial Landscapes of the Harappan Civilization in Proc Nat Acad Sci 109 E1688-94

Goslar T, Balaga K, Arnold M, Tisnerat N, Starnawska E, Kuzniarski M, Chrost L, Walanus, A and Wieckowski K (1999) Climate-related variations in the composition of the Late glacial and early Holocene sediments of Lake Perespilno (eastern Poland) in Quat Sci Rev 18 899-911

Guiot J (2011) Transfer functions IOP Conf Series: Earth and Environmental Sci 14 012008, doi: 101088/1755-1315/ $14 / 1 / 012008$

Gupta A K, Anderson D M and Overpeck J T (2003) Abrupt changes in the Asian southwest monsoon during the Holocene and their links to the North Atlantic Ocean in Nature 421 354-357

Harrison S P, Prentice I C and Guiot J (1993) Climatic controls on Holocene lake-level changes in Europe in Clim Dyn 8 189-200

Hodell D, Brenner M, Kanfoush S, Curtis J, Stoner J, Song X, Wu J and Whitmore T (1999) Paleoclimate of southwestern China for the past 50,000 yr inferred from lake sediment records in Quat Res 52 369-380

Jolly D, Harrison S P, Damnati B and Bonnefille R (1998) Simulated climate and biomes of Africa during the Late Quaternary. Comparison with pollen and lake status data. In: Webb, T. III (Ed.), Late Quaternary climates. Data Syntheses and model experiments in Quat Sci Rev 17 629657

Kar R, Bajpai R and Singh AD (2015) Modern pollen assemblages from Hamtah and Chhatru glaciers, Lahaul-Spiti, India: Implications for pollen-vegetation relationship in an alpine arid region of western Himalaya in Quat Internat DOI: dxdoiorg/ 101016/JQuaint201502 047

Kotlia B S and Joshi L M (2013) Neotectonic and climatic 
impressions in the zone of Trans Himadri Fault (THF), Kumaun Tethys Himalaya, India: A case study from palaeolake deposits in Zeitschrift für Geomorph 57 289303

Leggesse D, Gasse F and Radakovitch O (2002) Environmental changes in a tropical lake (lake Abiyata) Ethiopia during recent centuries in Paleogeog Paleoclimat Paleoecol 187 233-258

Luque J A and Julia R (2002) Lake sediment response to land-use and climate change during the last 1000 years in the oligotrophic Lake Sanabria (northwest of Iberian Peninsula in Sedim Geol 148 343-355

Madella M and Dorian Q F (2006) "Paleoecology and the Harappan Civilization of South Asia: A Reconsideration" in Quat Sci Rev 25 1283-1301

Maher B A and Hu M (2006) A high-resolution record of Holocene rainfall variations from the western Chinese loess Plateau: antiphase behaviour of the African/ Indian and east Asian summer monsoons in The Holocene 16 309-319

Mehrotra N, Shah S K and Bhattacharyya A (2014) Review of palaeoclimate records from Northeast India based on pollen proxy data of Late Pleistocene Holocene in Quat Internat $32541-54$

Mehrotra R, Soohoo M, Rivara M B, Himmelfarb J, Cheung A K, Arah O A, Nissenson A R, Ravel V, Streja E, Kuttykrishnan S, Katz R, Molnar M Z and KalantarZadeh K (2015) Racial and Ethnic Disparities in Use of and Outcomes with Home Dialysis in the United States in JAm Soc Nephrol ASN2015050472 [Epub ahead of print]

Meyers P A and Teranes J L (2001) Sediment organic matter. In: (Eds.: Smol W M and Last J P) Tracking Environmental Change Using Lake Sediments, vol 2: Physical and Geochemical Methods, Kluwer Academic Publishers, Dordrecht, The Netherlands 239-269

Mingram J, Allen J R M, Bruchmann C, Liu J, Luo X, Negendank J F W, Nowaczyk N and Schettler G (2004) Maar- and crater lakes of the Long Gang Volcanic Field (NE China)overview, laminated sediments, and vegetation history of the last 900 years in Quat Internat 123-125 135-147

Minyuk P S, Bringham-Grette J, Melles M, Borkhodoev, V Ya and Yu G (2007) Inorganic geochemistry of El'gygytgyn Lake sediments (northeastern Russia) as an indicator of paleoclimatic change for the last $250 \mathrm{kyr}$ in J Paleolimnol 37 123-133

Mishra P K, Anoop A, Schettler G, Prasad S, Jehangir A and Menzel P (2015) Reconstructed late Quaternary hydrological changes from Lake Tso Moriri NW Himalaya in Quat Internat 371 76-86
Misra S and Bhattacharyya A (2014) Analysis of the Late Holocene Climate vis-a-vis Vegetationdynamics along the South West coast of India:Thrissur (Kerala) in Quat Internat 325 150-161

Mohan R D (2014) Loss of Drosophila Ataxin-7, a SAGA subunit reduces $\mathrm{H} 2 \mathrm{~B}$ ubiquitination and leads to neural and retinal degeneration in Genes Dev 28 259-72

Nag D and Phartiyal B (2014) Climatic variations and geomorphology of the Indus RiverValley, between Leh and Batalik, Ladakh (NW Trans Himalayas) in Quat Inertnat http://dxdoiorg/101016/jquaint201408045

Nageswara Rao K, Subraelu P, Nagakumar K Ch V, Demudu G, Hema Malini B, Rajawat A S and Ajai (2013) Geomorphological implications of the basement structure in the Krishna-Godavari deltas, India in Zeitschrift fur Geomorph 57 25-44

Nair K, Babeesh C and Achyuthan H (2014) Late Quaternary Holocene Paleoenvironmental Reconstruction And Hydrodynamics Based On Some Lakes And Marine Sediments Of India: A Review in Jour of Geol Soc of Sri Lanka 16 159-170

Nair K M, Padmalal D, Kumaran KPN, Sreeja R, Limaye R B and Srinivas R (2010) Late Quat evolution of Ashtamudi Sasthamkotta Lake systems of Kerala, Southwest India in J Asian Earth Sci 37 361-372

Nandy S and Bandyopadhyay S (2011) Trends of sea level change in the Hugli estuary, India Indian in J Geo-Mar Sci 40 802812

Ng S L and King R H (2004) Geochemistry of lake sediments as a record of environmental change in a high Arctic watershed in Chem Erde 64 257-275

Osborne L L and Kovacic D A (1993) Riparian vegetated buffer strips in water-quality restoration and stream management in Freshwater Biol 29 243-258

Padmalal D, Maya K, Vishnu Mohan S and Baburaj B (2014) Holocene land-seainteractions and landform changes in the coastallands of Vembanad lagoon, Kerala, SW India in Indian J of Marine Sci $\mathbf{4 3}$ (In press)

Palanisamy H, Cazenave A, Meyssignac B, Soudarin L,Wöppelmann G and Becker M (2014) Regional sea level variability,total relative sea level rise and its impacts on islands and coastal zones of Indian Ocean over the last sixty years in Global Planet Change Doi:101016/ jgloplacha201402001

Parker A G, Goudie A S, Stokes S, White K, Hodson M J, Manning M and Kennet D (2006) A record of Holocene climate change from lake geochemical analyses in southeastern Arabia Quat Res 66 465-476 
Phartiyal B, Randheer Singh, Kothyari G Ch (2015) LateQuaternary geomorphic scenario due to changing depositional regimes in the Tangtse Valley, TransHimalaya, NW India in Palaeogeog Palaeoclimat Palaeoecol 422 11-24

Phartiyal B, Sharma A and Kothyari G Ch (2013) Damming of River Indus during Late Quaternary in Ladakh Region of Trans-Himalaya, NW India: Implications to Lake formation-climate and tectonics in Chinese Sci Bull $\mathbf{5 8}$ $142-155$

Piovano E, Ariztegui D, Bernasconi S M and McKenzie J A (2004) Stable isotopic record of hydrological changes in subtropical Laguna Mar Chiquita (Argentina) over the last 230 years in The Holocene 14 525-535

Polanski S, Fallah B, Befort D J, Prasad S and Cubasch U (2014) Regional moisture change over India during the past Millennium: A comparison of multi-proxy reconstructions and climate model simulations in Global and Planet Change 122 176-185

Ponton C, Giosan L, Eglinton T I, Fuller D Q, Johnson J E, Kumar P and Collett T S (2012) Holocene aridification of India in Geophys Res Lett 39 L03704 doi:10.1029/2011 GL050722

Possehl G L (1994) The Indus civilization in Man and Environ 19 103-113

Possehl G L (2002) The Indus Civilization: A Contemporary Perspective Altamira Press Lanham

Prasad S and Enzel Y (2006) Holocene paleoclimates of India in Quat Res 66 442-453

Prasad S, Kusumgar S and Gupta S K (1997) A mid- to late Holocene record of paleoclimatic changes from $\mathrm{Nal}$ Sarovar: a palaeodesert margin lake in western India in J of Quat Sci 12 153-159

Prasad V, Farooqui A, Sharma A, Phartiyal B, Chakraborty S, Bhandari S, Raj R and Singh A (2014) Mid-Late Holocene monsoonal variations from mainland Gujarat, India: A multi-proxy study for evaluating climate culture relationship in Palaeogeog Palaeoclimat Palaeoecol 397 $38-51$

Priyanka R, Achyuthan H, Eastoe C and Ramesh R (2016) Late quaternary paleoenvironmental shifts inferred from the Parsons Valley Lake sediments, Nilgiris, Tamil Nadu India in J of Paleolimnol (Under Review)

Purushothaman K, Puthiyottil S S V, Bhattacharya T and Muttath G (2015) In Regard to Salboch in Int J Radiat Oncol Biol Phys 93465

Quamar M F and Bera S K (2014a) Pollen production and depositional behaviour of teak (Tectona grandis Linn. f.) and sal (Shorea robusta Gaertn. f.) in tropical deciduous forests of Madhya Pradesh, India: An overview in Quat Inat 325 111-115

Quamar M F and Bera S K (2014b) Surface pollen and its relationship with modern vegetation in tropical deciduous forests of southwestern Madhya Pradesh, India: A Rev in Palynol 38 147-161

Raj R, Chamyal L S, Prasad V, Sharma A, Tripathi J and Verma P (2015) Holocene climatic fluctuations in the Gujarat Alluvial Plains based on multiproxy study of the Pariyaj Lake archive, western India in Paleogeog Paleoclimat Paleoecol $42162-74$

Ranjana and Farooqui A (2015) Relative Sea level, Climate and Geomorphological changes since $\sim 8 \mathrm{ka}$ in Krishna river delta in Internat J of Curr Res and Acad Rev India 3 303316

Rashid H, England E, Thompson L and Polyak L (2011) Late Glacial to Holocene Indian Summer Monsoon Variability Based upon Sediment Records Taken from the Bay of Bengal in Terr Atmos Ocean Sci 22 215-228

Robinson C (1994) Lago Grande di Monticchio, southern Italy: a long record of environmental change illustrated by sediment geochemistry in Chem Geol 118 235-254

Ross K A, Gashugi E, Gafasi A, Wüest A and Schmid M (2015) Characterisation of the Subaquatic Groundwater Discharge that Maintains the Permanent Stratification within Lake Kivu; East Africa in Plos One 10 e 0121217

Ruiz-Fernandez A C, Hillaire-Marcel C, Pae’z-Osuna F, Ghaleb $\mathrm{B}$ and Caballero M (2007) $210 \mathrm{~Pb}$ chronology and trace metal geochemistry at Los Tuxtlas, Mexico, as evidenced by a sedimentary Record from the Lago Verde Crater Lake in Quat Res 67 181-192

Sakai T, Minoura K, Soma M, Tani Y, Tanaka A, Nara F, Itoh N and Kawai T (2005) Influence of climate fluctuation on clay formation in the Baikal drainage basin in $J$ of Paleolimnol 33 105-121

Saxena A, Trivedi A, Chauhan MS and Sharma A (2015) Holocene vegetation and climate change in Central Ganga Plain: A study based on multiproxy records from Chaudhary-KaTal, Raebareli District, Uttar Pradesh, India in Quat Internat 371 164-174

Saxena V A, Prasad V and Singh IB (2013) Holocene palaeoclimate reconstruction from the phytoliths of the lake-fill sequence of Ganga Plain in Curr Sci 104 1054-1062

Schettler G, Schwab M J and Stebich M (2007) A 700-year record of climate change based on geochemical and palynological data from varved sediments (Lac Pavin, France) in Chem Geol 240 11-35 
Shen J, Liu X Q, Wang, S M and Matsumoto R (2005) Palaeoclimatic changes in the Qinghai Lake area during the last 18,000 years in Quat Internat 136 131-140

Singh D S, Gupta A K, Sangode S J, Clemens S C, Prakasam M, Srivastava P, Shailendra K and Prajapati S k (2015) Multiproxy record of monsoon variability from the Ganga Plain during 400-1200 AD in Quat Internat 371 157-163

Srivastava A K, Tiwari S, Devara P C S, Bisht D S, Srivastava M K, Tripathi S N, Goloub P and Holben B N (2011) Premonsoon Aerosol Characteristics over the Indo-Gangetic Basin: Implications to Climatic Impact in Ann Geophys 29 789-804

Srivastava J, Farooqui A and Hussain S M (2012) Vegetation history and salinity gradient during the last 3700 years in Pichavaram estuary, India in J of Earth Sys Sci 121 12291237

Srivastava J, Farooqui A and Hussain S M (2013) Climate induced Late-Holocene ecological changes in Pichavaram Estuary, India in Mari Ecol 34 474-483

Staubwasser M F, Sirocko P M, Grootes and Segl M (2003) Climate change at the $4.2 \mathrm{ka}$ BP termination of the Indus Valley civilization and Holocene south Asian monsoon variability in Geophys Res Lett 301425

Street F A and Grove A T (1979) Global maps of lake-level fluctuations since 30,000 years ago in Quat Res 12 83-118

Street-Perrott FA and Harrison S P (1985) Lake levels and climate reconstruction. In Paleoclimate Analysis and Modeling (Ed: Hecht AD) pp 291-340, Wiley, New York

Street-Perrott F A and Harrison S A (1984) temporal variations in lake levels since 30,000 yr BP- an index of the global hydrological cycle. In Climate processes and climate sensitivity: (Ed: Hansen J E and Takahashi T) in Ameri Geophys Union 118-129

Tamuntuan G, Bijaksana S, King J, Russell J, Fauzi U, Maryunani K, Aufa N and Safiuddin LO (2015) Variation of magnetic properties in sediments from Lake Towuti, Indonesia, and its paleoclimatic significance in Palaeogeog Palaeoclimat Palaeoecol 420 163-172

Tanaka H K M, Nakano T, Takahashi S and Niwa K (2007) Development of an emulsion imaging system for cosmicray muon radiography to explore the internal structure of a volcano, Mt Asama in Nucl Instrum Methods A 575 489497

Tapia P M, Fritz SC, Baker PA, Seltzer G O and Dunbar R B (2003) A late Quaternary diatom record of tropical climate history from Lake Titicaca (Peru and Bolivia) Palaeogeog Palaeoclimat Palaeoecol 194 139-164

Tripathi S, Basumatary S K, Singh V K, Bera S K, Nautiyal C M and Thakur B (2014) Palaeovegetation and climate oscillation of western Odisha, India: A pollen data-based synthesis for the Mid-Late Holocene in Quat Internat 325 83-92

Trivedi A, Chauhan M S, Sharma A, Nautiyal C M and Tiwari D P (2013) Record of vegetation and climate during Late PleistoceneeHolocene in Central Ganga Plain, based on multiproxy data from Jalesar Lake, Uttar Pradesh, India in Quat Internat 306 97-106

Trivedi A, Singh D S, Chauhan M S, Arya A, Bhardwaj V and Awasthi A (2011) Vegetation and climate change around Ropan Chhapra tal in Deoria district, the central Ganga plain during the last 1350 years in J Palaeont Soc of India 56 39-43

Unnikrishnan A S, Nidheesh A G and Lengaigne M (2015) Sealevel-rise trends off the Indian coasts during the last two decades in Curr Sci 108 966- 971

van Campo E, Cour P and Huang S (1996) Holocene environmental changes in Bagong Co basin (Western Tibet). 2. The pollen record in Paleogeog Paleoclimat Paleoecol $12049-63$

Veena M P, Achyuthan H, Eastoe C and Farooqui A (2014) A multi-proxyreconstruction of monsoon variability in the late Holocene, South India in Quat Internat 325 63-73

Veena M P, Achyuthan H, Eastoe C and Farooqui A (2015) Human impact and low-Land velliyanai Lake, South India-record since 3000yBP in Anthropocene 83-91

Vijayaraj R, Achyuthan H, Eastoe C and Farooqui A (2016) Early Holocene to present paleoenvironmental shifts and short climate events inferred from tropical wedlands and lake sediments, Kukkal lake,southern India: Geochemistry and palynology in The Holocene (Under Review)

Watanabe T, Matsunaka T, Nakamura T, NishimuraM, Izutsu Y, Minami M, Nara F W, Kakegawa T, Wang Jand Zhu L (2010) Last glacial-Holocene geochronology of sediment cores from a high-altitude Tibetan lake based on AMS ${ }^{14} \mathrm{C}$ dating of plant fossils Implications for paleoenvironmental reconstructions in Chem Geol 277 21-29

Wolf S A, Walker I J and Huntley D J (2008) Holocene coastal reconstruction,Naikoon peninsula Charlotte Islands, British Columbia; Geological Survey of Canada in Curr Res $1216 \mathrm{p}$

Wünnemann B, Demske D, Tarasov P, Kotlia B S, Reinhardt C, Bloemendal J, Diekmann B, Hartmann K, Krois J, Riedel F and Arya N (2010) Hydrological evolution during the last $15 \mathrm{kyr}$ in the Tso Kar lake basin (Ladakh, India), derived from geomorphological, sedimentological and palynological records in Quat Sci Rev 29 1138-1155 
Xue B, Sand Y and Xia W (2007) Environmental changes in Lake Taihu during the past century as recorded in sediment cores in Hydrobiologia $\mathbf{5 8 1}$ 117-123

Yanes C, Alvarez H and Jaffe R (2006) Geochemistry of a tropical lake (Lake Leopold) on pseudo-karst topography within the Roraima Group, Guyana Shield, Venezuela in Appl Geochem 21 870-886

Yang Z, Yao T, Huang C and Sun W (1997) The record of YD event in Guliya ice core in Chinese Sci Bull 42 1975-1978 (in Chinese)

Yu L, Nai' ang W, Zhuolun L, Xuehua Z and Chengqi Z (2013) Climatic and environmental change in Yanchi Lake, Northwest China since the Late Glacial: A comprehensive analysis of lake sediments in J Geog Sci 23 932-946
Zhang Y (2004) Mechanisms and dynamics of explosive volcanic and lake eruptions (in Chinese) In: (Ed.:Y Chen), Environment, Natural Hazards, and Global Tectonic of the Earth. Beijing: Higher Educ pp 39-95

Zhang Y, Zhang E, Yin Y, van Dijk M, Feng L, Shi Z, Liu M and Qina B (2010) Characteristics and sources of chromophoric dissolved organic matter in lakes of the Yungui Plateau, China, differing in trophic state and altitude in Limnol Oceanog 55 2645-2659

Zolitschka B, Francus P, Ojala AEK and Schimmelmann A (2015) Varves in lake sediments - a review in Quat Sci Reviews 117 1-41, DOI 101016/jquascirev201503019 